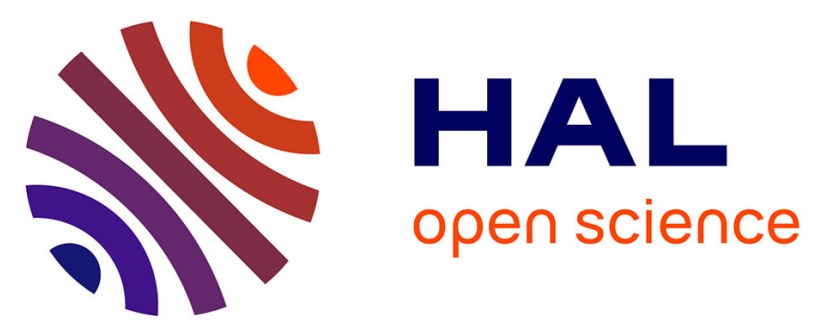

\title{
Middle to Late Pleistocene Evolution of the Bengal Fan: Integrating Core and Seismic Observations for Chronostratigraphic Modeling of the IODP Expedition $3548^{\circ}$ North Transect
}

\author{
Brendan Reilly, Fenna Bergmann, Michael Weber, Joseph Stoner, Peter \\ Selkin, Laure Meynadier, Tilmann Schwenk, Volkhard Spiess, Christian \\ France-Lanord
}

\section{- To cite this version:}

Brendan Reilly, Fenna Bergmann, Michael Weber, Joseph Stoner, Peter Selkin, et al.. Middle to Late Pleistocene Evolution of the Bengal Fan: Integrating Core and Seismic Observations for Chronostratigraphic Modeling of the IODP Expedition $3548^{\circ}$ North Transect. Geochemistry, Geophysics, Geosystems, 2020, 21 (4), 10.1029/2019GC008878 . hal-02547679

\section{HAL Id: hal-02547679 \\ https://hal.univ-lorraine.fr/hal-02547679}

Submitted on 28 May 2020

HAL is a multi-disciplinary open access archive for the deposit and dissemination of scientific research documents, whether they are published or not. The documents may come from teaching and research institutions in France or abroad, or from public or private research centers.
L'archive ouverte pluridisciplinaire HAL, est destinée au dépôt et à la diffusion de documents scientifiques de niveau recherche, publiés ou non, émanant des établissements d'enseignement et de recherche français ou étrangers, des laboratoires publics ou privés. 


\section{Geochemistry, Geophysics, Geosystems}

\author{
RESEARCH ARTICLE \\ 10.1029/2019GC008878 \\ Key Points: \\ - A novel regional \\ chronostratigraphic model is used to \\ investigate evolution of the lower \\ Bengal Fan over the last 1.25 Myr \\ - Seven IODP site chronologies are \\ constrained by lithostratigraphic, \\ magnetostratigraphic, \\ biostratigraphic, cyclostratigraphic, \\ and seismic stratigraphic constraints \\ - Growth and intensification of \\ channel-levee systems at $8^{\circ} \mathrm{N}$ \\ correspond to increases in the \\ amplitude of Pleistocene sea level \\ changes
}

Correspondence to:

B. T. Reilly,

btreilly@ucsd.edu

\section{Citation:}

Reilly, B. T., Bergmann, F., Weber, M. E., Stoner, J. S., Selkin, P., Meynadier, L., et al. (2020). Middle to late Pleistocene evolution of the Bengal Fan: Integrating core and seismic observations for chronostratigraphic modeling of the IODP Expedition 354 $8^{\circ}$ north transect. Geochemistry, Geophysics, Geosystems, 21, e2019GC008878. https://doi.org/ 10.1029/2019GC008878

Received 19 DEC 2019 Accepted 29 MAR 2020 Accepted article online 4 APR 2020

\section{Middle to Late Pleistocene Evolution of the Bengal Fan: Integrating Core and Seismic Observations for Chronostratigraphic Modeling of the IODP Expedition $3548^{\circ}$ North Transect}

\author{
Brendan T. Reilly ${ }^{1,2}$ (D), Fenna Bergmann ${ }^{3}$ (D) Michael E. Weber $^{4}$ (D) Joseph S. Stoner $^{1}(\mathbb{D}$, \\ Peter Selkin $^{5}$ iD, Laure Meynadier ${ }^{6}$, Tilmann Schwenk ${ }^{3}$ (D), Volkhard Spiess ${ }^{3}$ (D), \\ and Christian France-Lanord ${ }^{7}$ (D) \\ ${ }^{1}$ College of Earth, Ocean, and Atmospheric Sciences, Oregon State University, Corvallis, OR, USA, ${ }^{2}$ Scripps Institution of \\ Oceanography, University of California San Diego, La Jolla, CA, USA, ${ }^{3}$ Faculty of Geosciences, University of Bremen, \\ Bremen, Germany, ${ }^{4}$ Steinmann-Institute, University of Bonn, Bonn, Germany, ${ }^{5}$ School of Interdisciplinary Arts and \\ Sciences, University of Washington, Tacoma, WA, USA, ${ }^{6}$ Institut de Physique du Globe de Paris-Sorbonne Paris Cité, \\ Université Paris Diderot, Paris, France, ${ }^{7}$ Centre de Recherches Pétrographiques et Géochimiques, CNRS Université de \\ Lorraine, Vandoeuvre les Nancy, France
}

Abstract We investigate chronology and age uncertainty for the middle to upper Pleistocene lower Bengal Fan using a novel age-depth modeling approach that factors lithostratigraphic, magnetostratigraphic, biostratigraphic, cyclostratigraphic, and seismic stratigraphic constraints, based on results from the International Ocean Discovery Program Expedition 354 Bengal Fan and analysis of the GeoB97-020/027 seismic line. The initial chronostratigraphic framework is established using regionally extensive hemipelagic sediment units, and only age-depth models of fan deposits that respect the superposition of channel-levee systems between sites are accepted. In doing so, we reconstruct signals of regional sediment accumulation rate and lithogenic sediment input through the perspective of a two-dimensional $\sim 320 \mathrm{~km}$ transect at $8^{\circ} \mathrm{N}$ that are consistent with more distal and more ambiguous regional records. This chronology allows us to discuss the depositional history of the middle to upper Pleistocene lower Bengal Fan within the context of sea level, climate, and tectonic controls. We hypothesize, based on the timing of accumulation rate changes, that progradation and intensification of the Bengal Fan's channel-levee system at $8^{\circ} \mathrm{N}$ was largely driven by increases in sea level amplitude during this time. However, it is also possible this progradation was influenced by changes in Pleistocene climate and increased Himalayan erosion rates, driving greater sediment flux to the fan.

Plain Language Summary Deep sea fans are sediment deposits in the ocean that often form near river systems offshore continental margins. The largest of these, the Bengal Fan in the northern Indian Ocean, contains the most complete record of materials eroded from the Himalayan Mountains and can be used to study the climate and tectonic history of the region. Sediments are moved from the river mouth to the fan in a series of ever-changing channels that distribute sediments across the fan surface, making it impossible to obtain a complete and continuous record of Himalayan erosion at any one location. International Ocean Discovery Program Expedition 354 drilled a series of seven locations in a transect across the fan to capture a more complete record of where sediment was deposited over the last $1.25 \mathrm{Myr}$, a time characterized by major changes in Earth's climate system. Here we discuss statistics of sediment deposition from a computer model constrained by observations from those seven sites. The results indicate that the Bengal Fan grew rapidly during a time when global sea level changes, caused by the growth and decay of continental ice sheets, became more intense.

\section{Introduction}

The Bengal Fan is the final sink for a huge erosional system, containing the most complete record of Himalayan erosion since the start of the collision of India and Asia in the early Cenozoic (Curray, 1994; France-Lanord et al., 2016). However, the climate and tectonic signals recorded in these sediments are 


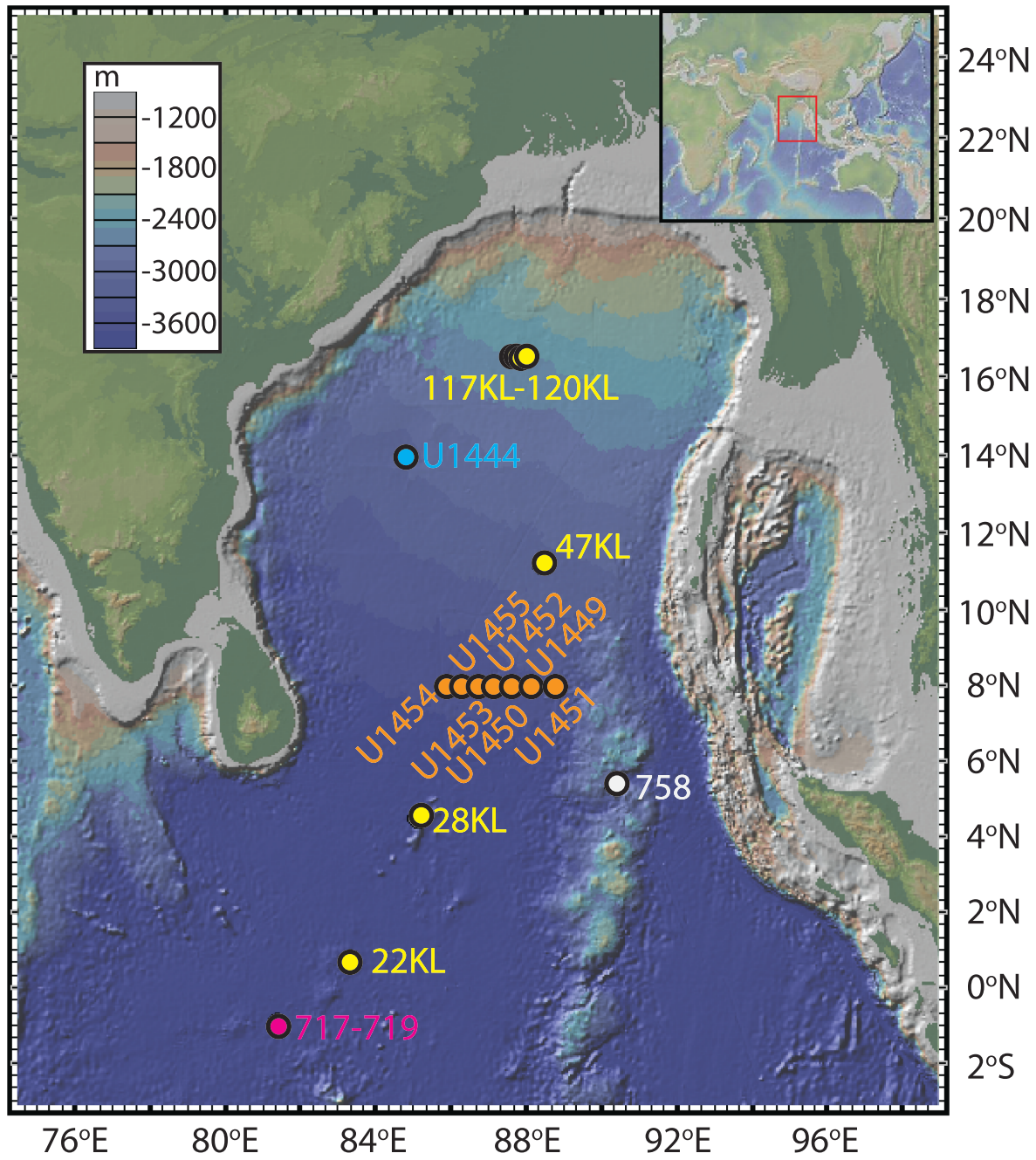

Figure 1. Locations of Bay of Bengal and Bengal Fan archives, including the IODP Expedition 354 transect (orange), IODP Expedition 353 Site U1444 (blue), SO93 cores (yellow), ODP Leg 116 sites (pink), and ODP Leg 121 Site 758 (white).

convolved during sediment transport through rivers, floodplains, deltas, the continental shelf, and ultimately the fan's channel-levee systems. Understanding the complete history of the erosional system is important as the uplift of the Himalaya is thought to have a significant impact on global climate over the Cenozoic, including the development of the Asian monsoonal systems (Zhisheng et al., 2001) as well as carbon sequestration by increased silicate mineral weathering (Raymo \& Ruddiman, 1992) and, perhaps more importantly, burial of organic carbon in its resulting deep sea fan sediments (France-Lanord \& Derry, 1997). Source to sink comparisons of organic carbon concentrations in river and fan sediments suggest near-perfect burial efficiency in the recent geologic past-in large part related to the very high accumulation rates of the Bengal Fan depositional system (Galy et al., 2007). Yet, complexities in fan depositional processes make it difficult to reconstruct time variations in integrated sediment flux and how these fluxes translate to sediment accumulation and associated organic carbon burial on the fan. To investigate the Pleistocene history of this depositional system, International Ocean Discovery Program (IODP) drilled a transect of seven sites along $8^{\circ} \mathrm{N}\left(\sim 320 \mathrm{~km} ; 85.85-88.74^{\circ} \mathrm{E}\right)$ and captured a range of lithologic units, including low accumulation rate hemipelagic deposits and high accumulation rate channel-levee influenced deposits which span at least the last $~ 1.25 \mathrm{Myr}$ at all sites (Figures 1-3 and Table 1; France-Lanord et al., 2016). This transect of cores, within the context of seismic imaging data, provides a two-dimensional perspective of the lower Bengal Fan's depositional history and an important step toward reconstructing comprehensive middle to late Pleistocene sediment budgets for the entire system. 


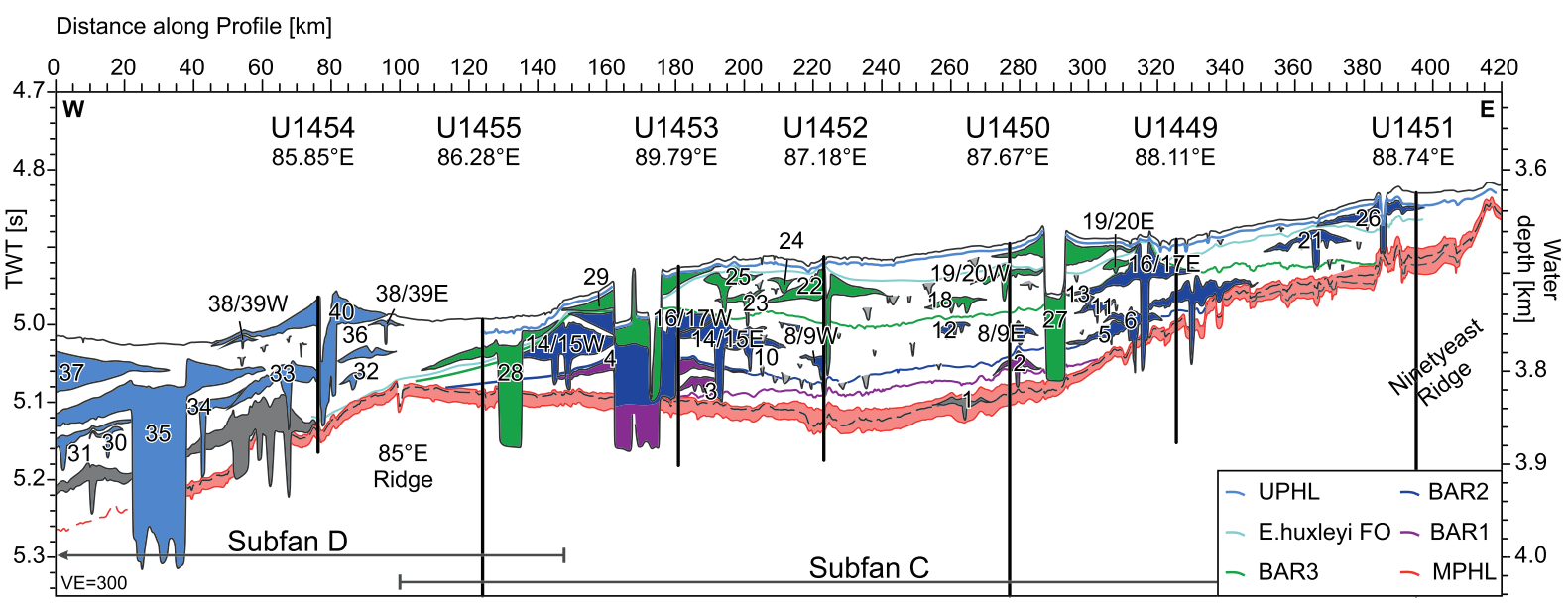

Figure 2. Seismic line GeoB97-020/027 with interpretation of Bergmann et al. (2020), highlighting the sediments studied here. IODP Expedition 354 Sites U1449U1455 are indicated with vertical black lines. Channel-levee systems are numbered after Bergmann et al. (2020) according to their stacking pattern (1 = oldest; 40 = youngest). Regionally extensive reflectors are highlighted, from oldest to youngest: the middle Pleistocene hemipelagic layer (MPHL; red shading); the Brunhes-Aged Reflectors: BAR 1 (magenta line), BAR 2 (dark blue line), and BAR 3 (green line); approximate reflector for the E. huxleyi datums (light blue line); and the base of the upper Pleistocene hemipelagic layer (UPHL; blue line). Colors of the Subfan C channel-levee deposits at sites west of IODP Site U1455 correspond to units above the BAR 1 (purple), BAR 2 (dark blue), and BAR 3 (green) reflectors. Subfan D channel-levee deposits are also indicated (light blue). Vertical exaggeration (VE) is 300. We refer the reader to Bergmann et al. (2020) for the uninterpreted seismic data.

A fundamental problem investigated by this study is that traditional age-depth modeling approaches for depositional systems like the Bengal Fan have trouble reconstructing accumulation rates that vary by orders of magnitude between interbedded lithologic units-in this case, the Bengal Fan's low accumulation rate hemipelagic sediments and high accumulation rate turbiditic sediments that are deposited when channel-levee systems are distant and proximal to the drill site, respectively. This is especially true when age control at any one site is limited, as was the case for the seven sites in the Expedition $3548^{\circ} \mathrm{N}$ transect. One cannot assign a single sedimentation rate distribution assumption to constrain uncertainty between age control points for both the hemipelagic and turbiditic sediments, as would be done with the Bacon method (Blaauw \& Christen, 2011). Nor should one allow for nearly every possible monotonic age-depth combination, as would be done with the Bchron method (Haslett \& Parnell, 2008), as this ignores first-order geologic observations that make many of these scenarios unreasonable. It would also be challenging to create age-depth models for each unit independently, as many of the fan units and thin calcareous clay units do not have reliable chronostratigraphic markers nor constraints on their start and end times.

To explore two-dimensional accumulation rate variations for the last 1.25 Myr and work toward a complete $8^{\circ} \mathrm{N}$ Bengal Fan chronostratigraphic framework for future studies, we employ a system-specific age-depth modeling approach that is inspired by well-established methods to address uncertainty (Blaauw \& Christen, 2011) but also incorporates expert knowledge about the Bengal Fan. Sediments deposited by gravity flow or hemipelagic depositional processes are objectively identified based on physical properties, and each lithology is modeled using different strategies. The law of superposition provides additional constraints in turbiditic deposits with few, if any, site-based constraints, by solving for all seven sites simultaneously and only accepting solutions that respect the channel-levee stacking pattern defined by Bergmann et al. (2020) (Figure 2). Here we analyze and discuss these model results. Our results allow for reconstruction of the time variation in integrated sediment flux at $8^{\circ} \mathrm{N}$ between $85.85^{\circ} \mathrm{E}$ and $88.74^{\circ} \mathrm{E}$. It also allows us to assess how representative each site is relative to the entire Expedition 354 transect for reconstructing past dynamics of the Bengal Fan. Implications for fan evolution and associated sedimentary processes are discussed in greater detail by Bergmann et al. (2020) and Bergmann (2018), while here we focus on the timing of depositional changes in relation to Pleistocene climate and sea level.

\subsection{The Pleistocene Bengal Fan}

Sediments are transported to $8^{\circ} \mathrm{N}$ on the Bengal Fan by turbidity currents along channel-levee systems, with the first evidence for channel-levee deposits from seismic imaging at $8^{\circ} \mathrm{N}$ during the late Miocene (Schwenk \& Spiess, 2009). In recent geologic times, channel-levee systems seem to be sourced to a single shelf canyon, 


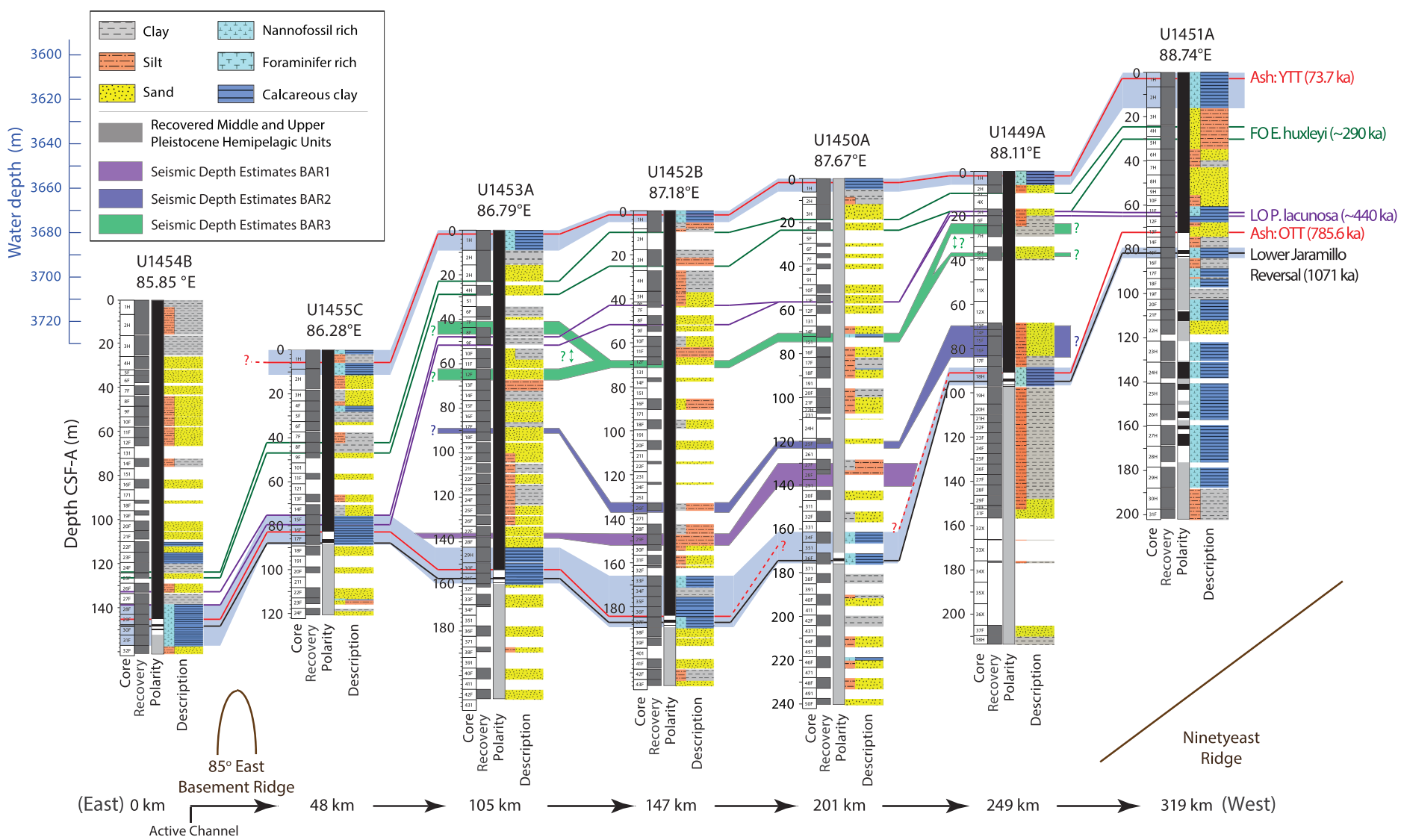

Figure 3. Stratigraphic summary of recovered sediments. Adapted from Weber and Reilly (2018) and France-Lanord et al. (2016). Ages for relevant chronostratigraphic markers are noted for ash layers (Mark et al., 2017), the upper and lower range of calcareous nanofossil datums (Gradstein et al., 2012), and the lower Jaramillo magnetic reversal (Channell et al., 2016). Where recovered, the OTT is always just beneath the Matuyama-Brunhes magnetic reversal (cf. Chesner, 2012; Lee et al., 2004; Smit et al., 1991). Magnetic polarity stratigraphy is updated from France-Lanord et al. (2016) for IODP Site U1451 after Reilly et al. (2018). Light blue shading indicates the regionally extensive thick middle and upper Pleistocene hemipelagic units. Seismic estimates of Bergmann et al. (2020) for the depth ranges of Brunhes-Aged Reflectors (BAR) $(1=$ purple; $2=$ blue; $3=$ green), which are generally associated with thin hemipelagic units where recovery is good, are also indicated. Question marks indicate uncertainty in tracing the BAR reflectors, including multiple possibilities of where BAR 3 intersects with IODP Sites U1453 and U1449.

the Swatch of No Ground (SoNG), and extend the 2,500 km length of the fan without bifurcation (Curray et al., 2003; Curray \& Moore, 1974; Weber et al., 1997); however, it is likely that separate shelf canyons existed for the Ganges and Brahmaputra rivers in the past (Blum et al., 2018). On Pleistocene timescales, frequent channel avulsions have caused the migration of active deposition across the entire fan (Bergmann et al., 2020; Curray et al., 2003; Schwenk \& Spiess, 2009). Bengal Fan channels are deeply incised into underlying deposits and show vertical aggregation and lateral migration (Schwenk et al., 2003, 2005). Fan depositional processes include the overspilling and flow stripping of channelized turbidity currents, which build channel levees, deposit interchannel sheet-like turbidites, and/or deposit massive sands (Piper \& Normark, 1983; Schwenk et al., 2005). Proximity to the channel-levee system is the primary control on sediment accumulation rate. Accordingly, no single drill site should be expected to contain a complete record of fan deposition on timescales longer than the life of a stable channel-levee system.

While it is likely that the highest fluxes of sediment were delivered to the fan during sea level low stands (Curray et al., 2003), direct radiocarbon dating of upper Pleistocene and Holocene levee turbidites (SO93 Cores $117-120 \mathrm{KL}, \sim 16.5^{\circ} \mathrm{N}$ ) demonstrate continued sediment input through the deglacial sea level rise and Holocene sea level high stand, with outer levee long-term accumulation rates around $70 \mathrm{~cm} / \mathrm{kyr}$, but often exceeding $100 \mathrm{~cm} / \mathrm{kyr}$ while sea level rose, and long-term accumulation rates from a location very proximal to the active channel were around $120 \mathrm{~cm} / \mathrm{kyr}$ for the last $9.6 \mathrm{kyr}$ (Hein et al., 2017; Weber 
Table 1

IODP Expedition 354 Holes Used in This Study

\begin{tabular}{lcccc}
\hline Hole & $\begin{array}{c}\text { Latitude } \\
\left({ }^{\circ} \mathrm{N}\right)\end{array}$ & $\begin{array}{c}\text { Longitude } \\
\left({ }^{\circ} \mathrm{E}\right)\end{array}$ & $\begin{array}{c}\text { Water } \\
\text { depth } \\
(\mathrm{m})\end{array}$ & $\begin{array}{c}\text { Meters used in model/cluster } \\
\text { analysis (total penetration) }\end{array}$ \\
\hline U1449A & 8.01 & 88.11 & $3,652.7$ & $120(213.5)$ \\
U1450A & 8.01 & 87.67 & $3,655.3$ & $190(687.4)$ \\
U1451A & 8.01 & 88.74 & $3,607.3$ & $110(582.1)$ \\
U1452B & 8.01 & 87.18 & $3,670.3$ & $195(217.7)$ \\
U1453A & 8.01 & 86.79 & $3,679.5$ & $180(215.7)$ \\
U1454B & 8.01 & 85.85 & $3,710.3$ & $170(161.8)$ \\
U1455C & 8.01 & 86.28 & $3,732.5$ & $110(949.0)$ \\
\hline
\end{tabular}

${ }^{\mathrm{a}}$ IODP Site U1455 is the reoccupation of Deep Sea Drilling Program (DSDP) Site 218, drilled during Leg 22. et al., 1997). Similar radiocarbon-based estimates preceding the deglacial sea level rise are not available at this time.

Previous efforts have had difficulty assigning ages and unambiguous relationships of paleochannel-levee systems, shelf canyons, and depocenter spatial extents. However, seismic evidence from the upper to lower fan suggests that a series of "subfans," resulting from spatial restriction of the active channel-levee systems for timescales ranging from about 250-500 kyr, occurred during the Pleistocene (Bergmann et al., 2020; Curray et al., 2003; Schwenk \& Spiess, 2009). During periods of local fan inactivity, when sediment routing moves the active fan depocenter elsewhere, calcareous clay sediments drape inactive channel-levee systems and other fan deposits (Bahk et al., 2019; Bergmann et al., 2020; Weber et al., 2003, 2018; Weber \& Reilly, 2018). These types of sediment are well documented in the upper stratigraphy of Core SO93-47KL $\left(11.18^{\circ} \mathrm{N}\right)$, where turbiditic activity ceased $\sim 0.3 \mathrm{Ma}$ (Weber et al., 2003) and Core U1452C-1H $\left(8^{\circ} \mathrm{N}\right)$, where turbiditic activity ceased $\sim 0.2 \mathrm{Ma}$ (Weber et al., 2018). These observations provide constraints for the abandonment of local channel-levee systems on the eastern fan before the late Pleistocene movement of the depocenter to the more western fan documented in seismic data (Subfan D of Bergmann et al., 2020; Subfan D1 of Schwenk \& Spiess, 2009).

Prior to sediments recovered during IODP Expedition 354 Bengal Fan, all older age constraints for the Pleistocene evolution of the upper-lower Bengal Fan were rooted in the stratigraphy of Deep Sea Drilling Program (DSDP) Site 218, which suffered partial coring and low recovery $(59.4 \mathrm{~m}$ of sediment from a $773 \mathrm{~m}$ hole), limited biostratigraphic constraints, and ambiguity in core-seismic comparison beyond prominent continuous reflectors (Von der Borch et al., 1974). While this was sufficient to get a sense for long-term sediment accumulation rates at that site and to provide first-order age estimates of Pleistocene depocenter changes within the context of seismic data (Curray et al., 2003; Schwenk \& Spiess, 2009), its chronology could not constrain fan dynamics on $\sim 100 \mathrm{kyr}$ timescales which are important for understanding fan evolution in the context of Pleistocene sea level and climate.

There are clues that major changes in fan deposition occurred during the Pleistocene. Results from Ocean Drilling Program (ODP) Sites 717 and 719 on the distal Bengal Fan $\left(\sim 1^{\circ} \mathrm{S}\right)$ show a significant increase in sediment accumulation rates between the last occurrences of small Gephyrocapsa spp. dominance ( 1.02 Ma) and Psuedoemiliania lacunosa ( 0.44 Ma), often reported as occurring at $0.8 \mathrm{Ma}$, with long-term accumulation rates switching from values on the order of a few $\mathrm{cm} / \mathrm{kyr}$ in the early and middle Pleistocene to values on the order of tens of cm/kyr after the switch (Gartner, 1990; ages updated according to Gradstein et al., 2012). This accumulation rate change was accompanied by sedimentological changes (clay mineralogy, particle size) that could be interpreted as a change in the erosional regime of the Himalayan and flood plain source regions, but, through comparison to the remarkably consistent clay mineralogy and lithology found in coeval Pleistocene sediments recovered during IODP Expedition 354, the lithologic changes found at ODP Sites 717 and 719 are more likely a reflection of changes in sediment transport and/or provenance to the distal fan (France-Lanord et al., 1993, 2016).

Perhaps the best dated complete Pleistocene record from the region is ODP Site 758 on the Ninetyeast Ridge $\left(5.38^{\circ} \mathrm{N}\right.$; recently redrilled as IODP Site U1443; Clemens et al., 2016), whose benthic $\delta^{18} \mathrm{O}$ record (Chen et al., 1995) was used in the construction of the LR04 benthic $\delta^{18} \mathrm{O}$ stack (Lisiecki \& Raymo, 2005). While no fan deposits are found in the mostly pelagic stratigraphy of ODP Site 758, researchers have argued that changes in the concentration of lithogenic sediments, tracked by magnetic susceptibility (MS), reflect a regionally integrated signal of climate, tectonic, and/or sea level-controlled inputs to the Bay of Bengal and Bengal Fan (Farrell \& Janecek, 1991; Klootwijk et al., 1992; Prell \& Kutzbach, 1997; Zhisheng et al., 2001). Isotopic evidence from 3-34 ka sediments of the Ninetyeast Ridge suggests that the lithogenic fraction may be a mix of Ganges and Brahmaputra sources, the primary sources of Bengal Fan SO93 Cores 117-120KL levee sediments (Hein et al., 2017; Lupker et al., 2013), and other river systems like the Irrawaddy (Ahmad et al., 2005). While the record suggests an increase in lithogenic sediments from the middle to late Pleistocene, it is difficult to understand the processes that drive this signal without context from the fan itself. 
IODP Expedition 354 reoccupied DSDP Site 218 (IODP Site U1455) along with six other sites along $8^{\circ} \mathrm{N}$ (IODP Sites U1449-U1454; Figures 1-3 and Table 1) with significantly better recovery and less disturbance than possible in 1972, thanks in part to the advent of the IODP half advanced piston corer (France-Lanord et al., 2016). Fortuitously, all seven sites recovered a regionally extensive calcareous clay unit with good reversal magnetostratigraphy_including the Matuyama-Brunhes Boundary (0.774 Ma), Jaramillo Subchron (1.071-0.990 Ma), and/or Cobb Mountain Subchron (1.208-1.187 Ma; ages according to Channell et al., 2016)_and consistent physical properties (France-Lanord et al., 2016; Weber \& Reilly, 2018) that also appears as a prominent reflector in seismic imaging, providing firm isochron horizons and core-seismic correlation in the middle Pleistocene (Bergmann et al., 2020). This unit, referred to in this study as the middle Pleistocene hemiplegic unit, has been discussed in previous studies as the "Middle Pleistocene Hemiplegic Layer" (Bergmann et al., 2020; Weber \& Reilly, 2018) and the "lower calcareous mud" (Bahk et al., 2019). In the upper part of this unit, some turbidites are intercalated with calcareous clay; however, there were no turbidites recovered at any of the Expedition 354 sites for at least $300 \mathrm{kyr}$, between marine isotope stages (MIS) 37 and 25, about 1.24-0.97 Ma (MIS ages according to Lisiecki \& Raymo, 2005; Unit 2a in Weber \& Reilly, 2018).

Additionally, thick upper Pleistocene hemipelagic sediments (previously discussed as the "Late Pleistocene Hemipelagic Layer" (Bergmann et al., 2020; Weber \& Reilly, 2018) and the "upper calcareous mud” (Bahk et al., 2019)) were recovered in the uppermost stratigraphy at all sites except the westernmost Site U1454 located next to the most recently active channel (France-Lanord et al., 2016; Weber \& Reilly, 2018). Using the middle and upper Pleistocene hemipelagic units to establish an initial chronostratigraphic framework, we investigate age-depth relationships at all seven sites for the last $\sim 1.25 \mathrm{Myr}$. This is an interesting period of time to study, as $1.25 \mathrm{Ma}$ marks the start of increased $1 / 100 \mathrm{kyr}^{-1}$ frequency amplitude in the benthic $\delta^{18} \mathrm{O}$ record driven by changes in the behavior of the major ice sheets (Clark et al., 2006), whose transition through the middle and late Pleistocene impacts the evolution of glacial-interglacial changes on sea level (Elderfield et al., 2012; Rohling et al., 2014) and monsoonal systems (Clemens et al., 1996; Sun et al., 2006, 2019) which have a largely unknown influence on the Bengal Fan sedimentary system.

\section{Materials and Methods}

Model design is discussed in section 2.1, and inputs to the model in section 2.2. For this study, we use the single hole at each IODP Expedition 354 site that best recovered middle to upper Pleistocene aged sediments (Table 1), as most intervals were only recovered in one hole at each site. Hole recovery, lithology, and some important chronostratigraphic markers are summarized in Figure 3. A detailed discussion of all chronostratigraphic constraints is given in Weber and Reilly (2018), building on the results of France-Lanord et al. (2016), and briefly summarized in section 2.2. Core depths in this study refer to the core depth below sea floor-B (CSF-B) scale, which applies a compression algorithm if recovery is greater than $100 \%$ to prevent overlap of recovered core with adjacent core intervals. This is necessary for this study, as uncertainty in drilling depth and core expansion led some stratigraphic markers to overlap on the primary CSF-A scale. When working with specific cores in each hole, CSF-B can be converted back to CSF-A using tables available through IODP.

$\mathrm{X}$-ray fluorescence $(\mathrm{XRF})$ data were collected from the surface of u-channel samples $(2 \times 2 \times$ up to $150 \mathrm{~cm}$ plastic tubes) over discrete intervals from IODP Site U1452 to supplement shipboard data using the ITRAX XRF core scanner at the Oregon State University Marine and Geology Repository. Data were collected every $1 \mathrm{~mm}$ with $5 \mathrm{~s}$ count time at $30 \mathrm{kV}, 55 \mathrm{~mA}$, and using a Mo tube. We present the $\mathrm{Ca} / \mathrm{Ti}$ ratio, a proxy for variations in lithogenic and calcareous biogenic sediments, to provide additional insight for the interpretation of shipboard nondestructive measurements. Additional data with sufficient counts per second were collected for $\mathrm{Si}, \mathrm{K}, \mathrm{Ca}, \mathrm{Ti}, \mathrm{Mn}, \mathrm{Fe}, \mathrm{Ni}, \mathrm{Cu}, \mathrm{Zn}, \mathrm{Br}, \mathrm{Rb}, \mathrm{Sr}, \mathrm{Zr}$, and $\mathrm{Ba}$ and are archived in the IODP community of the Zenodo. org repository along with other data to support this study (DOI: http://doi.org/10.5281/zenodo.3676057).

\subsection{System-Specific Age-Depth Modeling}

Our age modeling approach is inspired by well-established methods, primarily the Bacon method of Blaauw and Christen (2011), and utilizes the "t-walk" algorithm of Christen and Fox (2010), a Markov Chain Monte Carlo (MCMC) sampler. The algorithm is implemented in MATLAB, using the code of Colin Fox with the corrections by Andreas Nilsson ((Nilsson et al., 2018); available at www.cimat.mx/ jac/twalk/). While the 
t-walk may be less efficient than other MCMC methods, it requires little tuning and can be applied to a diverse set of MCMC problems by nonexperts. MCMC methods are used to estimate posterior distributions (model output; in this study, sediment accumulation, age-depth relationships, and their respective uncertainty) given prior distributions (model input; in this study, assumptions about sediment accumulation rates in hemipelagic sediments and age control points, with their respective uncertainties) through random sampling and optimizing an "energy" function. We refer the reader to Blaauw and Christen (2011) for a more detailed discussion of the t-walk and how it can be applied to sediment accumulation modeling. Here, we focus on the fundamental principles and highlight the differences between this method and Bacon. The fundamental concept presented here is that while we can define a prior (input) distribution for hemipelagic sediment accumulation due to good independent age constraints, turbiditic deposits have unconstrained accumulation rates.

In our model, the Expedition 354 holes are broken into a series of sections $\left(c_{1}, c_{2}, \ldots c_{i}\right)$ between depth intervals $\left(d_{0}, d_{1}, d_{2}, \ldots d_{i}\right)$ with section width $\left(\Delta c_{i}\right.$; all depths in $\left.\mathrm{cm}\right)$. Turbiditic deposits are nominally divided into $10 \mathrm{~m}$ intervals, while calcareous clay deposits are divided into $1 \mathrm{~m}$ intervals. Interval thickness was determined as an acceptable trade-off between model resolution and computational time. As each lithostratigraphic unit is not perfectly divisible by 10 or $1 \mathrm{~m}$, section widths are allowed to be smaller when needed. Sediment accumulation over a given time interval $(A$; in $\mathrm{kyr} / \mathrm{cm})$ in section $i$ is modeled as

$$
A_{i}=\left(1-w_{i}\right) \alpha_{i}+w_{i} \alpha_{i+1}
$$

where $\alpha$ is a randomly sampled sediment accumulation value (in $\mathrm{kyr} / \mathrm{cm}$ ) and $w$ is a memory parameter that determines the dependence of $\alpha$ on the preceding interval, where $w=0$ means $\alpha_{i}$ is independent of $\alpha_{i+1}$ and $w=1$ means $\alpha_{i}$ is equal to $\alpha_{i+1}$. In our model, $w$ is always equal to 0 at the base of the section, at lithologic transitions, and in turbiditic deposits. Because we use unevenly spaced depth intervals, and $w$ is dependent on interval spacing, for any interval $w_{i}=w_{p}{ }^{\Delta C i}$, where the memory has an exponential relationship with the lag (i.e., $\Delta c_{i}$; in cm). In the calcareous clay sediments, $w_{p}$ is the memory value randomly selected according to the prior beta distribution (Beta $\left(a_{w}, b_{w}\right)$ ) (see Blaauw \& Christen, 2011). We require that all values of $w$ be between 0 and 1 and that all $\alpha$ values, for turbiditic or hemipelagic deposits, are positive (i.e., monotonic accumulation). For hemipelagic sediments, we use a memory (i.e., w) mean of 0.7 and strength of 30 (equivalent to $a_{w}=21$ and $b_{w}=9$ ).

Sediment age at any depth $\left(t_{D}\right.$ in $\left.\mathrm{ka}\right)$ is calculated as

$$
t_{D}=\sum_{d=1}^{D} \Delta c_{d}^{*} A_{d}
$$

assuming that the sediment water interface is at age 0 .

We provide a prior in which hemipelagic sediments $\alpha_{h}$ are described by a gamma distribution (Gamma $\left(a_{\alpha h}\right.$, $\left.b_{\alpha h}\right)$ ) (after Blaauw \& Christen, 2011) while turbiditic sediments are left unconstrained. Based on observations where age control is strong (Weber \& Reilly, 2018), we use accumulation mean of $3 \mathrm{~cm} / \mathrm{kyr}$ (i.e., $1 / \alpha$ ) and two accumulation shapes to define the distribution (equivalent to $a_{\alpha h}=2$ and $b_{\alpha h}=6$ ).

An "energy" function is used as the input to the t-walk algorithm as $U(\alpha, w \mid y)=-\log f\left(\alpha, w \mid y_{1}, y_{2}, \ldots y_{i}\right)$ which represents the $-\log$ of the posterior distribution, where $y$ are the magnetic reversal, tephra, and orbital tuning age constraints (in ka) with uncertainty $\left(\sigma\right.$; in kyr) at depth $\left(D_{1}, D_{2}, \ldots D_{i}\right.$; in cm). In this case

$$
\begin{aligned}
& U(\alpha, w \mid y)=-\left(1-a_{w}\right) \log w_{p}-\left(1-b_{w}\right) \log \left(1-w_{p}\right)- \\
& \sum_{i=1}^{I}\left(1-a_{\alpha h}\right) \log \alpha_{i h}+b_{\alpha h} \alpha_{i h}- \\
& \sum_{j=1}^{J} \log \sigma_{j}+\left(\frac{y_{j}-t_{D j}}{\sigma_{j}}\right)^{2} / 2
\end{aligned}
$$

This "energy" function differs with respect to Bacon, as we have relatively simple probability distribution for our age constraints (i.e., we assume all normal distributions, rather than calibrated radiocarbon dates) and we set the sediment water interface to a constant value of $0 \mathrm{ka}$; thus, the three lines of equation 3 relate to fitting the memory, hemipelagic accumulation rates, and age constraint priors, respectively. 
To ensure that our solutions are geologically meaningful, we implement a few additional hard constraints, where if violated, the "energy" function is set to - Inf and the iteration is rejected. First, all solutions must respect the maximum limiting date provided by the first occurrence of Emiliania huxleyi, where only solutions that the first occurrence is younger than $290 \mathrm{ka}$ are accepted. Second, all solutions must respect the channel-levee stacking pattern of Bergmann et al. (2020). This is achieved by solving for all seven sites simultaneously using the t-walk algorithm and rejecting any solution by setting the "energy" function to -Inf where the base of a stratigraphically higher channel-levee system is modeled as being older than the top of a channel-levee systems that is stratigraphically lower.

\subsection{Lithostratigraphic and Chronostratigraphic Inputs for Age-Depth Modeling}

Sediments recovered in the upper $200 \mathrm{~m}$ of each site were categorized as hemipelagic or related to gravity flow processes (e.g., turbidites, channel-levee, interlevee, and sand deposits) deposits by fitting a Gaussian mixture model cluster analysis to three physical properties measured on ship: MS, natural gamma radiation (NGR), and sediment lightness $\left(L^{*}\right)$. We removed measurements made within $3 \mathrm{~cm}$ from the edge of each section and normalized MS and NGR by gamma ray attenuation (GRA) estimated wet bulk density using the method of Walczak et al. (2015) by smoothing all records to the same resolution using a full width at half maximum (FWHM) Gaussian filter of $6 \mathrm{~cm}$ and resampling every $5 \mathrm{~cm}$. While $L^{*}$ was not normalized, we also filtered and resampled to allow for direct comparison. Intervals that were not recovered by coring were categorized as hemipelagic or turbiditic deposits based on the closest overlying or underlying sediments recovered. If both agreed, all sediments in between were classified as being the same. If both disagreed, the depth of the contact was assigned at random.

Bergmann et al. (2020) discuss the identification of channel-levee deposits and prominent reflectors in detail, and the reader is referred to their study for a more in-depth discussion of the core-seismic integration. We use their interpretation and number scheme of the channel-levee stacking pattern at $8^{\circ} \mathrm{N}$ (Figure 2). Their integration of cores and seismic data was conducted with constant velocities ranging from 1,640 to $1,680 \mathrm{~m} / \mathrm{s}$ for the different sites (Bergmann et al., 2020). Velocities were determined by the best fit of prominent reflectors with lithologic boundaries and physical properties. Velocities were also cross-checked with the shipboard measured $P$ wave velocities. While there are uncertainties in any time-depth conversion, broad agreement in the calculated depths of the high-amplitude reflectors associated with calcareous clay and turbiditic contacts and drilling depths lends confidence in their use in this study.

We use age constraints from Weber and Reilly (2018) which establish an orbital resolution chronology in middle to upper Pleistocene calcareous clay sediments through correlation of $L^{*}$ variations to the benthic $\delta^{18} \mathrm{O}$ timescale of Lisiecki and Raymo (2005) within the framework of biostratigraphic and magnetostratigraphic constraints. Along the Expedition 354 transect and other sites from the lower Bengal Fan, including cores with expanded calcareous clay lithologies SO93 Cores $22 \mathrm{KL}, 28 \mathrm{KL}$, and 47KL, $L^{*}$ primarily reflects the relative proportion of biogenic calcareous to lithogenic sediments (Weber et al., 2003). At IODP Site U1452, upper Pleistocene calcareous clay sediments were studied in detail and display $L^{*}$ variations on orbital timescales along with planktonic $\delta^{18} \mathrm{O}$ and other proxies that reflect marine productivity and sediment composition (Weber et al., 2018). In our model, we assign an uncertainty of $7 \mathrm{kyr}(1 \sigma)$ to account for uncertainties in correlation (human uncertainty) and phase (geologic uncertainty) with the benthic $\delta^{18} \mathrm{O}$ reference template.

We include additional constraints from magnetic reversals, using the timescale of Channell et al. (2016), which is based on direct benthic $\delta^{18} \mathrm{O}$ and magnetic comparison in North Atlantic IODP Site U1308 and provides stronger constraints on the timing of the Cobb Mountain Subchron with respect to the benthic $\delta^{18} \mathrm{O}$ timescale than the Geologic Timescale of Gradstein et al. (2012) used in the Expedition 354 Proceedings (France-Lanord et al., 2016). These tuned reversal ages are assigned uncertainty of 5 kyr. Two tephra layers recovered at most sites are interpreted as the Youngest Toba Tephra and Oldest Toba Tephra (France-Lanord et al., 2016; Weber et al., 2018; Weber \& Reilly, 2018). We assign the ${ }^{40} \mathrm{Ar} /{ }^{39} \mathrm{Ar}$ dates for these events with their analytical uncertainty, $73.7 \pm 0.3$ and $785.6 \pm 0.7 \mathrm{ka}$, of Mark et al. (2017) as additional age control points. Biostratigraphic datums are treated with caution, as the last occurrence of $P$. lacunosa (440 ka) was found in the same samples as E. huxleyi (first occurrence at $290 \mathrm{ka}$ ) in multiple holes (Holes U1450A and U1454B), suggesting reworking of very old materials in turbiditic deposits, and many turbiditic and sandy samples were barren, making it challenging to establish first and last occurrence depths with confidence (all nannofossil ages after Gradstein et al., 2012). While these issues likely do not impact 
calcareous clay sediments, until further biostratigraphic work refines shipboard estimates, the biostratigraphic markers cannot be used as tie points for establishing a 10-100 kyr resolution chronology. In our model, however, we do include the first occurrence of $E$. huxleyi as a maximum limiting date, because even if the nannofossil is reworked from its actual first occurrence the interpretation does not change (i.e., if a sample contains E. huxleyi, the sample must be less than $290 \mathrm{ka}$ old). When additional constraints become available, they can be incorporated to improve the age-depth model results.

\subsection{Stacking Model Results}

We build two stacks using the model results to represent the regional signals captured by the Expedition 354 $8^{\circ} \mathrm{N}$ transect. Sediment accumulation rates were calculated for each of the age-depth combinations at each site over $1 \mathrm{kyr}$ intervals to capture $1 \mathrm{kyr}$ and greater changes in long-term accumulation rates. These were used to calculate statistics for each site and for the transect as a whole. Similarly, a MS stack was created by applying the median age-depth relationship for each site to logarithmically transformed shipboard point MS (log (MS)) records and resampling every 1 kyr, after applying a smoothing Gaussian filter with FWHM of $2.5 \mathrm{kyr}$. These smoothed and resampled $\log (\mathrm{MS})$ records were then stacked to extract a signal that is representative of the whole transect.

\section{Results}

\subsection{Lithostratigraphy}

Results of the Gaussian mixture model are summarized in Figures 4 and 5. We choose a three-cluster solution, as it describes the data in a geologically meaningful way without overfitting the data. In comparison to the shipboard descriptions of primary lithology, Cluster 1 was mainly described as calcareous clay, Cluster 2 was mainly described as sands, and Cluster 3 was described as a mixture of lithogenic clays, silts, and sands. Accordingly, we interpret Cluster 1 as describing hemipelagic sediments and Clusters 2 and 3 as describing sediments delivered by gravity flow processes, such as massive sands deposited in sand lobes and turbidites (e.g., Schwenk et al., 2005).

MS, which tracks the concentration of magnetizable material, is generally highest in sandy fan sediments (Cluster 2) over muddy (clayey-sandy) turbidites (Cluster 3), suggesting a particle size control on MS values, consistent with previous observations for Bengal Fan sediments (Weber et al., 2003). Dilution of the relative proportion of lithogenic sediments by biogenic sediments is likely the primary control on the low MS values in hemipelagic sediments (Cluster 1). It is possible, but difficult to assess at this time, that there are either bedrock or weathering source controls on MS as well, as was suggested in the study of distal fan mud turbidities (Sager \& Hall, 1990) and Bay of Bengal slope sediments (Phillips et al., 2014). $L^{*}$ values are similar for both turbiditic sediment clusters but exhibit a much greater range in hemipelagic sediments, reflecting orbital timescale controls on sediment composition in the hemipelagic sediments, as documented elsewhere on the fan (Weber et al., 2003, 2018). NGR, which tracks the amount of radioactive materials, is likely on first order related to the relative concentration of lithogenic materials and on second order related to the relative proportion of K-, U-, and Th-bearing minerals in the lithogenic fraction. There is a strong negative correlation with $L^{*}$ in hemipelagic sediments, suggesting this reflects variations in biogenic and lithogenic contributions. Conversely, there is a strong positive correlation in NGR and MS in sandy fan sediments, suggesting whatever is controlling the concentration of magnetic minerals is also controlling the concentration of $\mathrm{K}$-, U-, and/or Th-bearing minerals.

\subsection{Seismic Reflection Data}

The multichannel seismic profile GeoB97-020/27 crosses all seven IODP Expedition 354 sites. In addition to the seismic stratigraphy discussed by Bergmann et al. (2020) we identified three regionally continuous and high-amplitude reflectors above the middle Pleistocene hemipelagic layer east of IODP Site U1453, which we name the Brunhes-Aged Reflectors (BAR) 1, 2, and 3 (Figures 2 and 3). BAR 1 onlaps the middle Pleistocene hemipelagic layer between Sites U1450 and U1449 (approximately at km 305, Figure 2). BAR 2 onlaps the middle Pleistocene hemipelagic layer east of Site U1449 between approximately km 330-350 (Figure 2). BAR 3 can be traced until approximately km 380-390, just west of Site U1451, where it onlaps the middle Pleistocene hemipelagic layer. The western termination of the three layers is masked by a set of channel-levee systems (Numbers 4, 16/17 W, and 29 in Figure 2). Where core recovery is good, these 

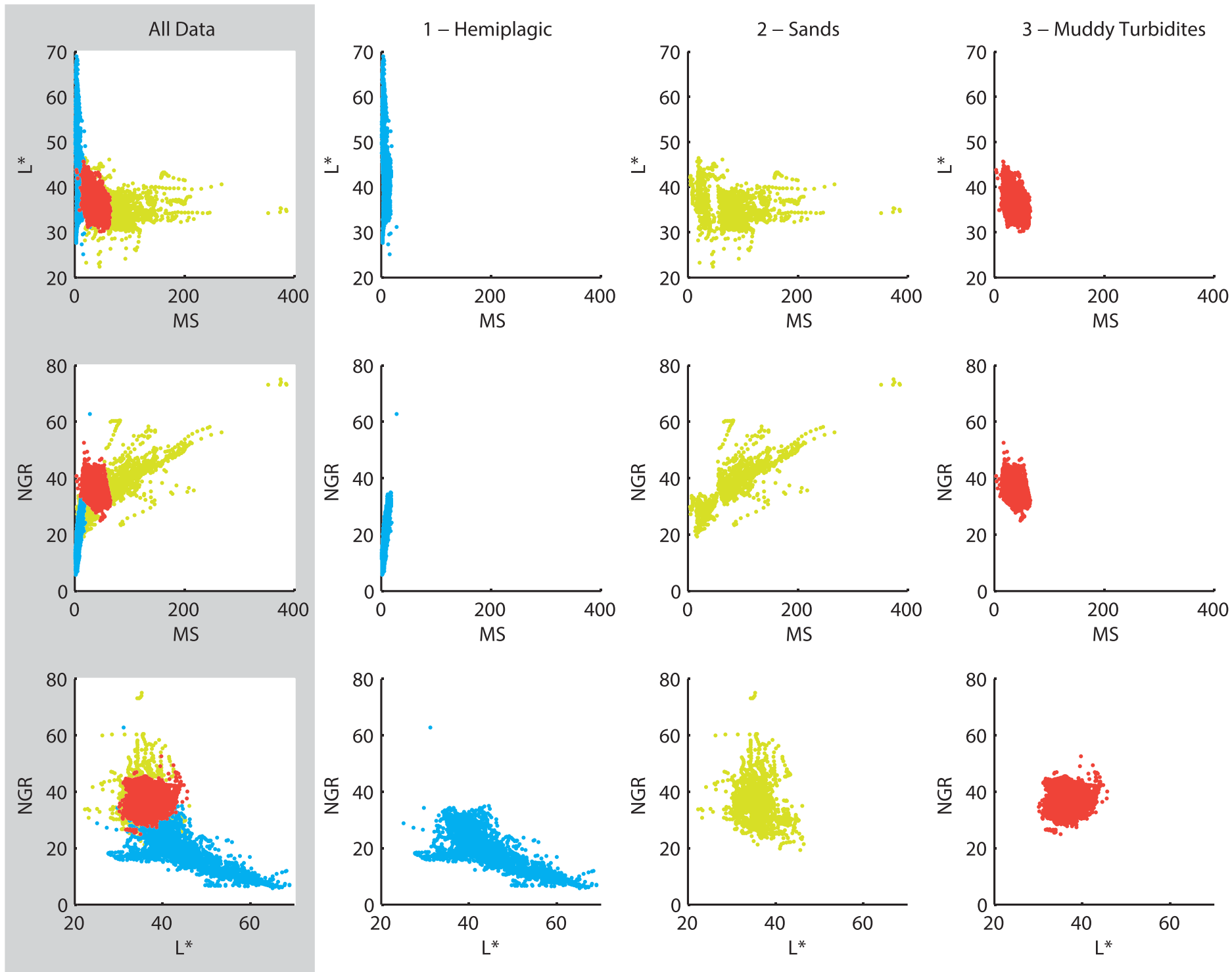

Figure 4. Comparison of physical properties and results of the cluster analysis. Natural gamma radiation (NGR) and magnetic susceptibility (MS) were normalized by gamma ray attenuation (GRA) estimates of bulk density following the method of Walczak et al. (2015).

reflectors appear to be the result of the impedance contrasts between thin calcareous clay sediments and coarse-grained turbiditic sediments (e.g., Figure 6).

\subsection{Age-Depth Models}

Following Blaauw and Christen (2011), we only sample every 100th realization of the t-walk. Goodness of fit relative to the prior distribution is tracked by the - $\log$ of the energy function (equation 3). Since the initial conditions poorly fit the prior distributions, a set of saved iterations needs to be removed as the t-walk converges on solutions with good fit. We remove the first 15,000 of the saved iterations based on where the $-\log$ of the energy function seems to stabilize, leaving 70,284 iterations, or age-depth combinations that respect stratigraphic relationship for each site of the transect, to use in our analysis (Figure 7). As expected, based on our model inputs, sediments identified as hemipelagic by the cluster analysis have low accumulation rates, while turbiditic sediments have higher accumulation rates.

Accumulation rates are widely variable on our model outputs, reflecting a combination of the actual accumulation rate variability and uncertainty of our model itself. We calculate the distributions of accumulations rates calculated over $1 \mathrm{~m}$ intervals from the ensemble of age-depth models for hemipelagic and turbiditic 
(a)

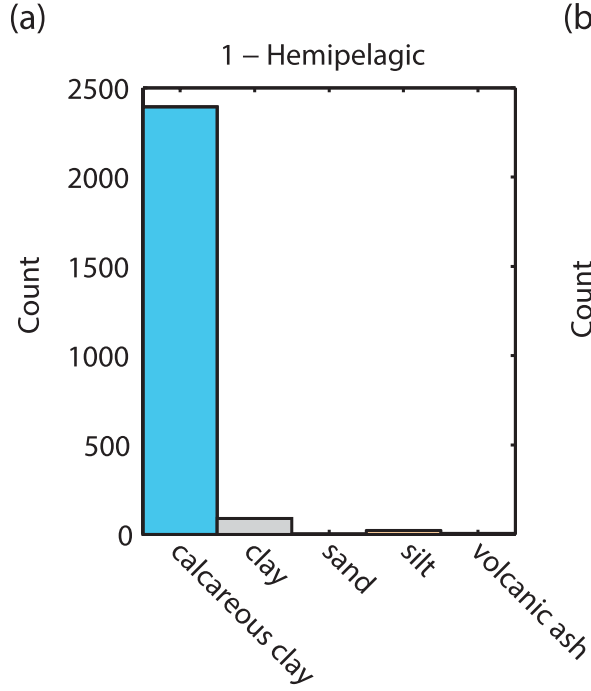

(d)

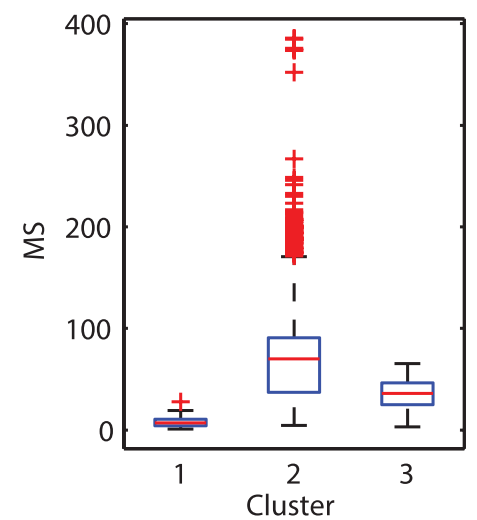

(b)

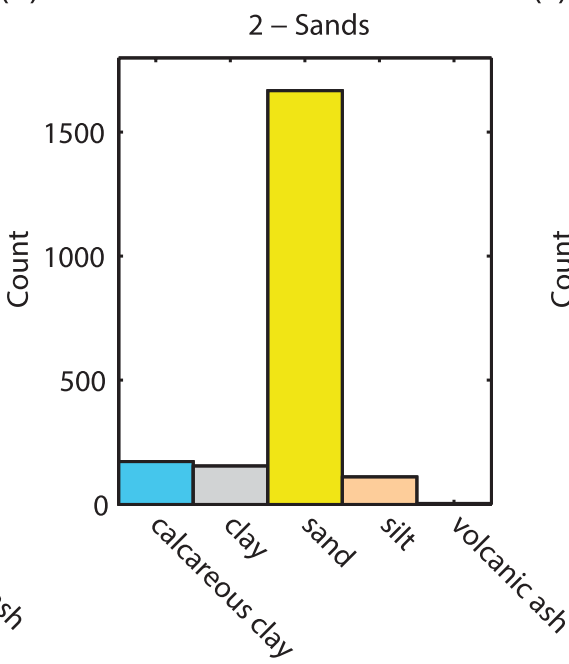

(e)

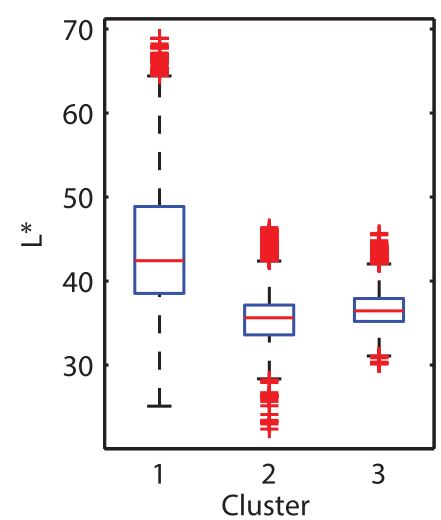

(c)

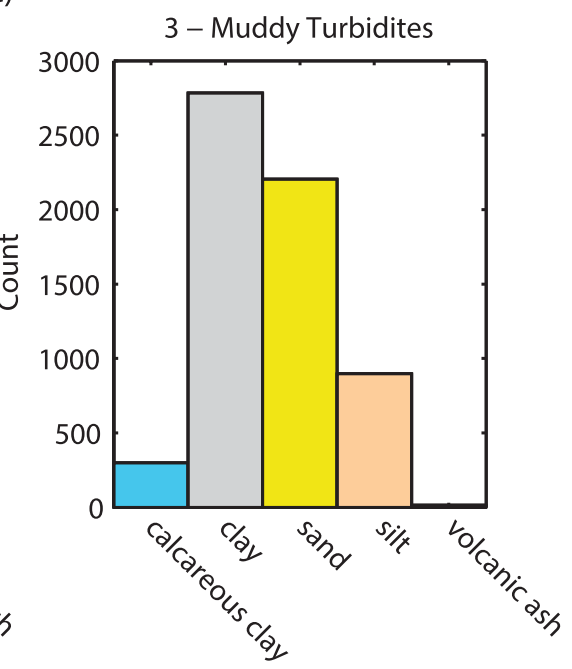

(f)

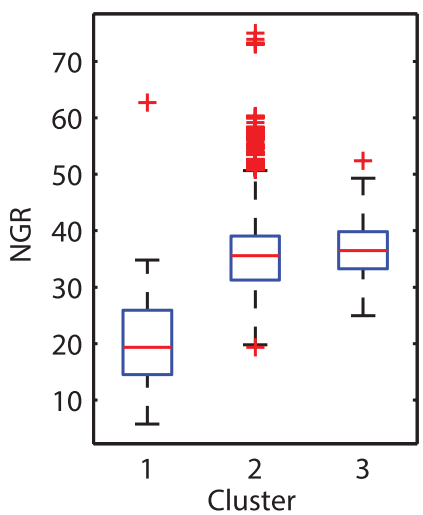

Figure 5. Comparison of cluster analysis results with shipboard visual core descriptions. Note that Cluster 1 (a) was primarily described as calcareous clay and can be interpreted as hemipelagic sediment while Clusters 2 (b) and 3 (c) were mostly described as various mixtures of lithogenic clays, silts, and sands and can be interpreted as sediments primarily deliver by gravity flow processes. Box and whisker plots (d-e) show the median (horizontal red line), range of the second and third quartiles (box), and 99.3\% range (whiskers) for the three physical properties-magnetic susceptibility (MS), sediment lightness ( $\left.L^{*}\right)$, and natural gamma radiation (NGR)—used in the cluster analysis.

deposits, based on the designation from our cluster analysis results (Figure 8). Median accumulation rates for hemipelagic deposits range from $\sim 2$ to $6 \mathrm{~cm} / \mathrm{kyr}$ for the seven sites, and distributions range from about $10^{0}$ to $10^{1} \mathrm{~cm} / \mathrm{kyr}$. Often these distributions are multimodal with modes around 2 and $5 \mathrm{~cm} / \mathrm{kyr}$. The lowest median accumulation rates are at IODP Sites U1454 and U1449, the latter of which is the site with best chronologic control in the middle Pleistocene and longest recovered sequence without intercalated turbidites, due to a thick sequence recovered in Core U1449A-18H that exhibits no turbiditic influence between the Jaramillo Subchron and Matuyama-Brunhes boundary relative to other sites (see Weber \& Reilly, 2018). High median hemipelagic accumulation rates were modeled for IODP Site U1450. This is likely in part a result of drilled intervals U1450A-33I and 35I (Figure 3), which limited recovery of middle Pleistocene hemipelagic sediments and associated age control points-notably that IODP Site U1450 was the only site that did not recover the Matuyama-Brunhes magnetic reversal or the Oldest Toba Tephra (France-Lanord et al., 2016; Figure 3). Other sites, such as U1452, have distributions that include higher hemipelagic accumulation rates and were noted to have frequent fine-grained turbidites intercalated with calcareous clay sediments near the top of the middle Pleistocene hemipelagic layer. The differences noted in sites like U1449 versus U1452 are also observed in variations of the thickness of the middle Pleistocene hemipelagic layer in the seismic imaging, with IODP Site U1449 capturing one of the thinnest examples and IODP Site U1452 capturing one of the thickest (Bergmann et al., 2020). 


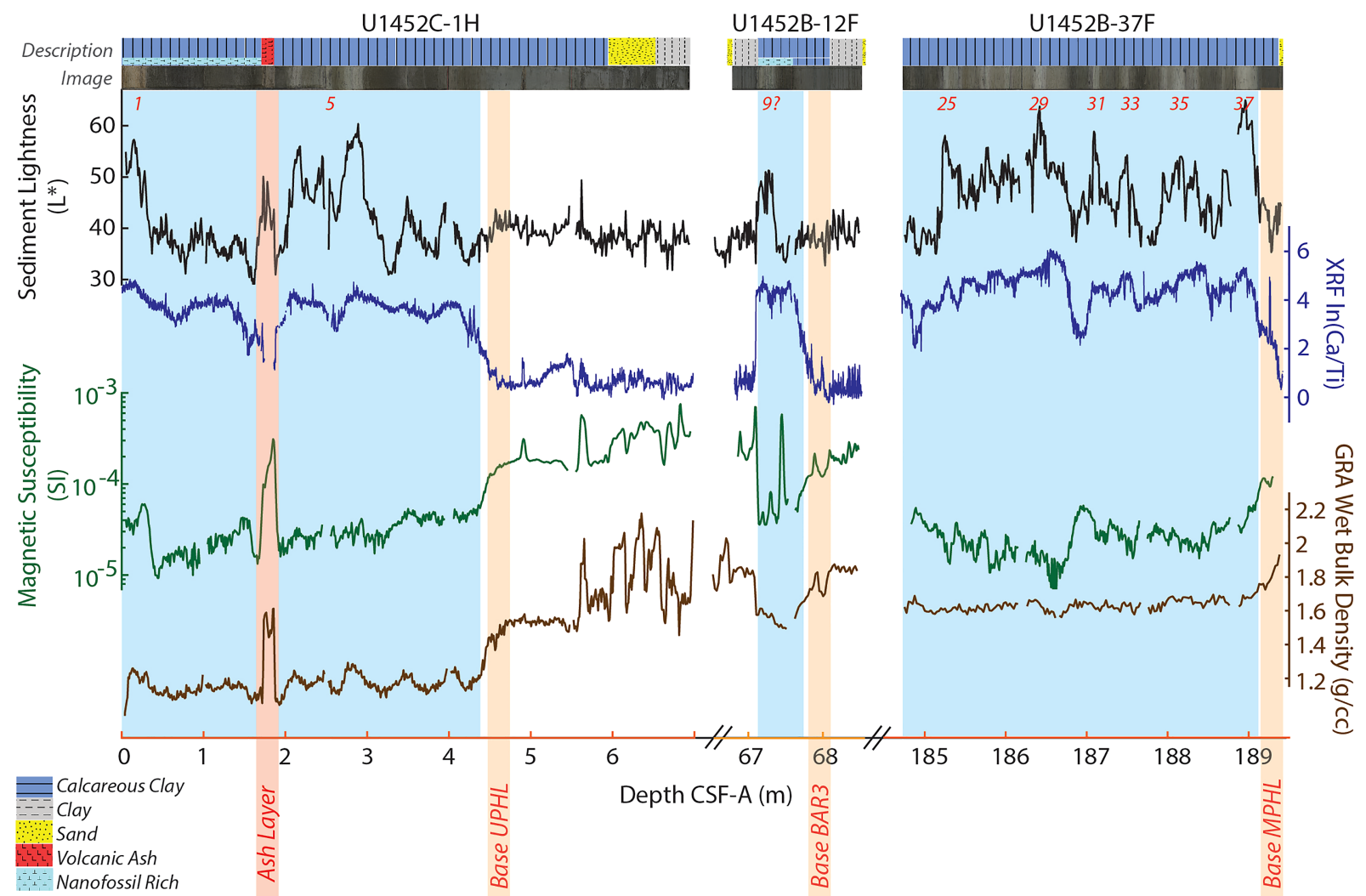

Figure 6. Shipboard measured physical properties, sediment lightness $\left(L^{*}\right)$ and magnetic susceptibility (MS), and gamma ray attenuation (GRA)-derived wet bulk density compared with the XRF ratio of $\mathrm{Ca}$ to Ti for hemipelagic sediments and their contacts with turbiditic sediments at IODP Site U1452. These contacts include the base of the upper Pleistocene hemipelagic layer (UPHL), the hemipelagic layer associated with Brunhes-Aged Reflector 3 (BAR 3), and the middle Pleistocene hemipelagic layer (MPHL). Shipboard lithologic descriptions and images are included for reference. There is a stark contrast between high MS, low $\mathrm{Ca} / \mathrm{Ti}$, and high GRA in turbiditic deposits and low MS, high Ca/Ti, and low GRA in hemipelagic sediments. $L^{*}$ highs in hemipelagic deposits can be used to identify sediments deposited during interglacial times (Weber et al., 2018). Blue shading indicates the hemipelagic sediments deposited with little influence from gravity flow processes, which is different than shipboard descriptions of calcareous clay sediments.

Turbiditic deposit accumulation rate distributions are much wider, ranging from about $10^{0}$ to $10^{4} \mathrm{~cm} / \mathrm{kyr}$. While we expect accumulation rates to be widely variable in these sediments, much of this spread is related to not using a turbiditic accumulation rate distribution prior (input) in our model (see section 2.1 System-Specific Age-Depth Modeling). Median accumulation rates range from $\sim 40$ to $120 \mathrm{~cm} / \mathrm{kyr}$, with the spatial pattern of median accumulation rate following the same pattern as seismic stratigraphic thickness between IODP Sites U1454 and U1449 and with the thickest deposits found between the $85^{\circ}$ East Basement Ridge and Ninetyeast Ridge (Schwenk \& Spiess, 2009).

The spatial pattern of median modeled sediment accumulation rates, calculated over 1 kyr time intervals, indicate that the earliest episodes of high, $>10^{1} \mathrm{~cm} / \mathrm{kyr}$, long-term accumulation rates occurred near the center of the transect following deposition of the middle Pleistocene hemipelagic unit (Figure 8). These high accumulations are modeled earliest at IODP Site U1450, which is consistent with the stratigraphically oldest channel-levee systems identified above the middle Pleistocene hemipelagic layer in seismic imaging (Figure 2); however, as mentioned earlier, IODP Site U1450 was also the only site to not recover the Matuyama-Brunhes Boundary and accordingly has worse age control than the other sites. High accumulation rates spread outward, following the stacking pattern defined by Bergmann et al. (2020), and ultimately switch to the highest accumulation rates at our westernmost site, IODP Site U1454, between 200 and $300 \mathrm{ka}$. IODP Site U1455 is the only site that experiences very high accumulation rates near the base of the middle Pleistocene hemipelagic unit, likely related to incomplete recovery of the middle Pleistocene hemipelagic unit leading to no constraints from the Cobb Mountain Subchron (France-Lanord et al., 2016). 

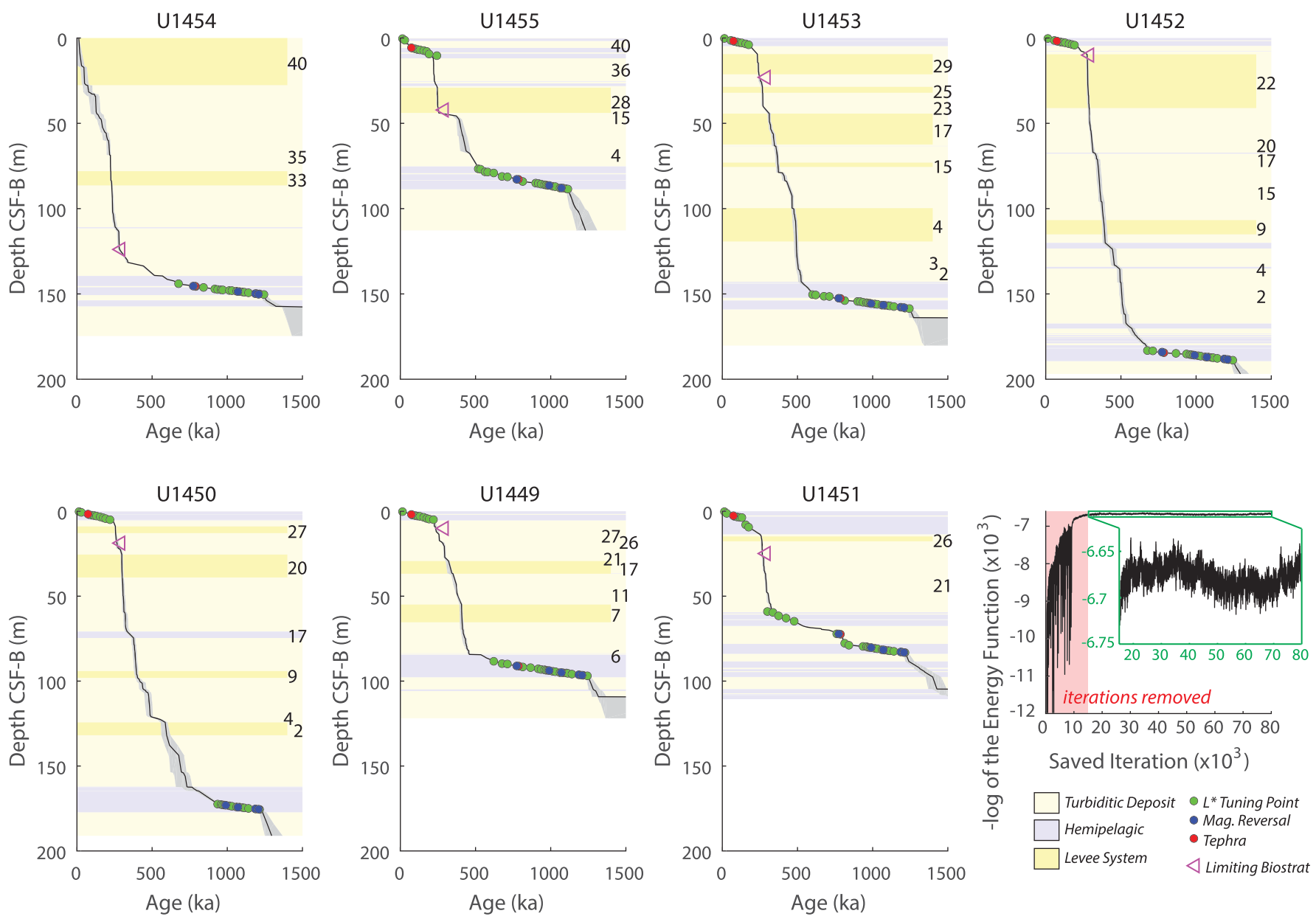

Figure 7. Age-depth models with median age (black line) and 99\% confidence intervals (gray shading) for all IODP Expedition 354 sites. Representative stratigraphy for turbiditic (yellow) and hemipelagic (blue) deposits are included for reference. Levee systems of Bergmann et al. (2020) highlighted in darker yellow and numbered as in Figure 2. Fifteen thousand model runs were removed as early iterations that have poor fits to the prior distribution, tracked by lower values of the $-\log$ of the energy function (equation 3).

\section{Discussion}

\subsection{Assessing the Ages of Regionally Extensive Brunhes-Aged Reflectors}

The three regionally extensive high-amplitude reflectors above the thick middle Pleistocene hemipelagic unit, BAR 1-3 (Figures 2 and 3), often where core recovery was good, correlate with thin ( 1 m) calcareous clay units in the cores (e.g., Figure 6). This suggests that the impedance contrast between hemipelagic and turbiditic deposits create these reflectors and they represent time intervals of widespread low accumulation along the $8^{\circ} \mathrm{N}$ transect. $L^{*}$, XRF geochemistry, and MS found in the unit that correlated with the youngest of the three reflectors, BAR 3, are consistent with a transition from glacial (low MS, low $L^{*}$ ) to interglacial sediments (low MS, high $L^{*}$ ) with a sharp upper contact that could be erosional (Figure 6). It is more difficult to interpret the nature of sediments associated with BAR 1 and BAR 2, but this could be related to core recovery or erosion of the upper hemipelagic surface. Nonetheless, the presence of these regionally continuous reflectors suggests turbiditic sediments deposited after deposition of the middle Pleistocene hemipelagic unit were delivered in a series of pulses.

We investigate the ages and potential timing of each BAR so that we can discuss possible fluxes of sediment to $8^{\circ} \mathrm{N}$ during each of the associated turbiditic units. To do so, we calculate the age distributions from our age models of the predicted depth range (deepest estimate to shallowest estimate), according to Bergmann et al. (2020), of each BAR where they are observed to cross an IODP Expedition 354 site (Figure 9). Age distributions are often wide, illustrating the large uncertainty of ages in turbiditic sediments between the thick 


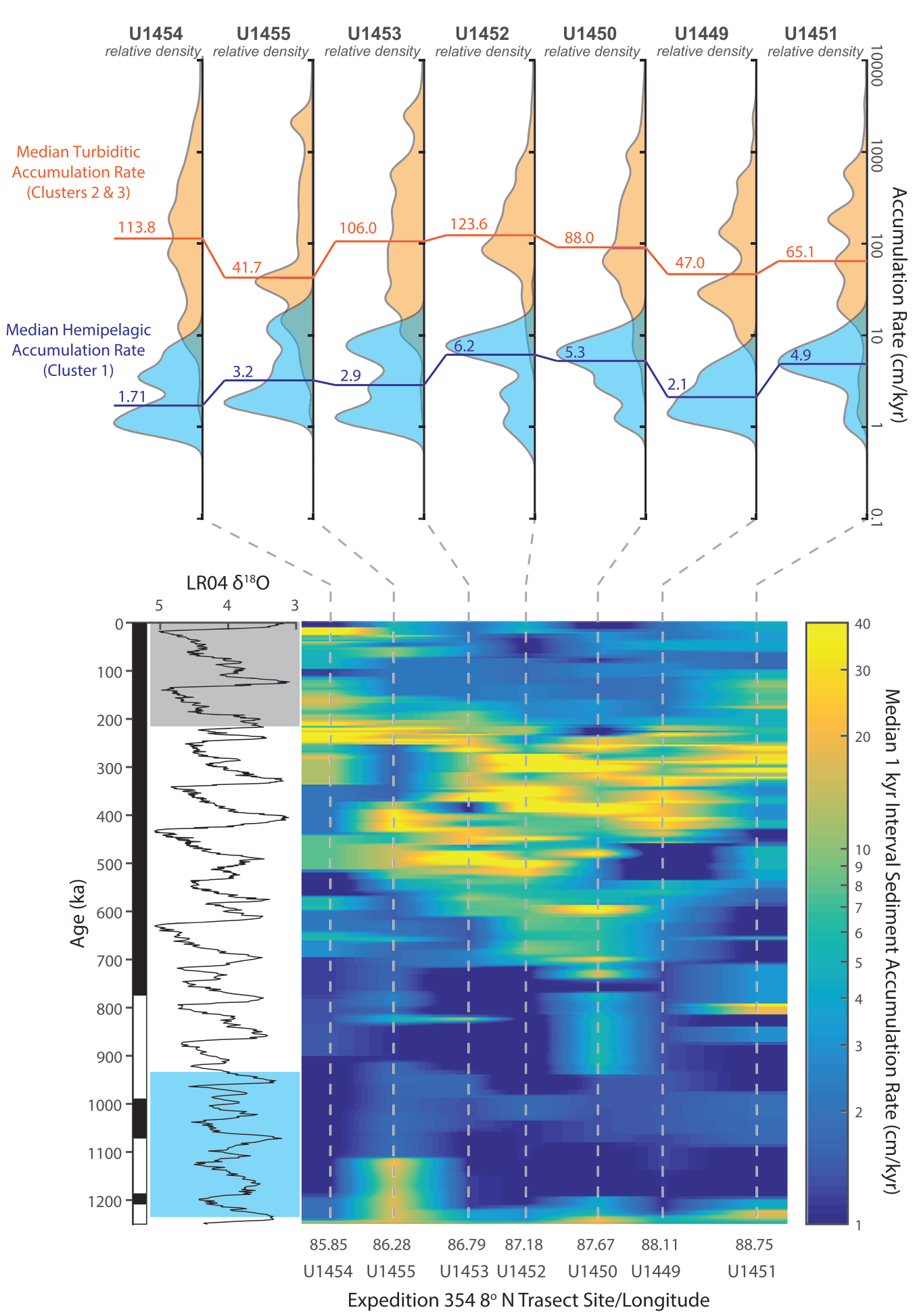

Figure 8. Resulting sediment accumulation rates from the age-depth models presented in Figure 7. (top) Sediment accumulation rate kernel density estimates (horizontal axis is the relative density of accumulation rates over $1 \mathrm{~m}$ intervals found in all model iterations) for turbiditic deposits (orange) and hemipelagic deposits (blue) with median values in $\mathrm{cm} / \mathrm{kyr}$ indicated as horizontal lines for each site. (bottom) Median modeled accumulation rates calculated in 1 kyr time increments plotted as an interpolated surface against longitude and time. The LR04 benthic $\delta^{18} \mathrm{O}$ stack (Lisiecki \& Raymo, 2005) with the magnetic polarity timescale (Channell et al., 2016) is plotted for reference, with greater $\delta^{18} \mathrm{O}$ values indicating times of increased ice volume, cooler deep ocean temperatures, and lower sea level. The blue shaded interval represents the time period where no turbidites were observed along the $8^{\circ} \mathrm{N}$ transect and age control is best (Weber \& Reilly, 2018). High accumulation rates at IODP Site U1455 at the base of this unit is likely related to incomplete recovery of the middle Pleistocene hemipelagic layer at this site (France-Lanord et al., 2016). The gray shaded interval indicates the interval where the depocenter is focused on the western fan, as recognized in seismic data (Bergmann et al., 2020; Schwenk \& Spiess, 2009). 


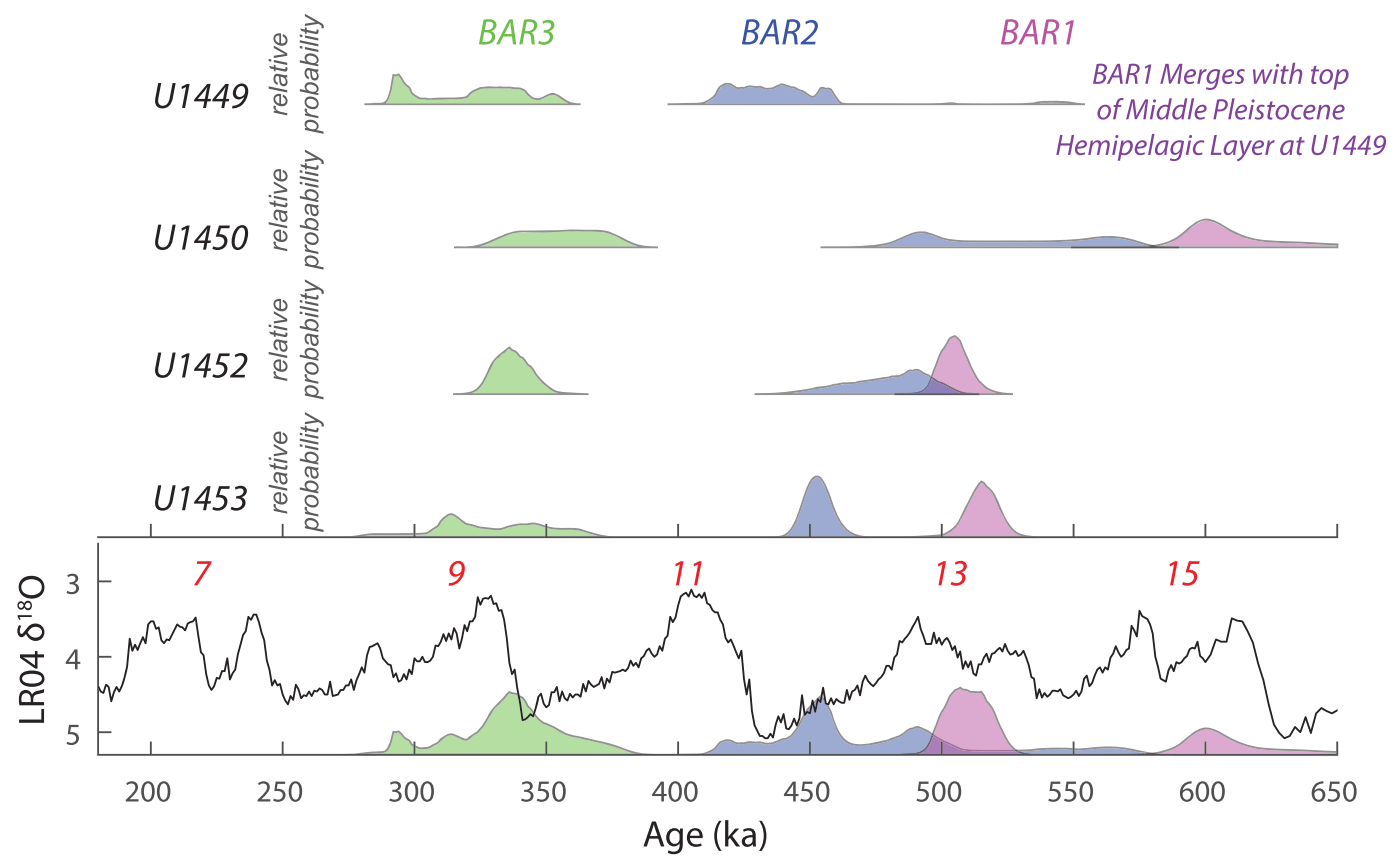

Figure 9. Relative age probability distributions of Brunhes-Aged Reflectors (BAR) 1 (green), 2 (blue), and 3 (purple), calculated from all ages in the interval between the uppermost and lowermost depth estimates based on seismic data. The bottom panel includes the sum probability distribution of all observations. The LR04 benthic isotope stack with interglacial marine isotope stage (MIS) numbers is included for comparison (Lisiecki \& Raymo, 2005).

regionally extensive middle and upper Pleistocene hemipelagic units; however, most age distributions are within uncertainty of each other. IODP Site U1450 is an exception to this with BAR 1 significantly older than estimates at other sites. This may be the result of limited recovery and fewer age control points in the middle Pleistocene as discussed in section 3.3.

The BAR 3 age distribution only spans one major glacial-interglacial transition and was likely deposited around the transition from glacial MIS 10 to interglacial MIS $9(\sim 0.34 \mathrm{Ma})$, based on sedimentological observations from IODP Site U1452 (Figure 6). BAR 1 at IODP Sites U1452 and U1453 seems to be most consistent with being deposited during MIS 13. This is consistent with tracing the layer to merge with the uppermost middle Pleistocene hemipelagic unit at IODP Site U1449, which experiences little turbiditic influence and can be dated to at least MIS 15, with additional hemipelagic sediment above that marker (Weber \& Reilly, 2018). Given that BAR 1 and BAR 3 are likely associated with interglacial sea level high stands, it is tempting to assign BAR 2 to MIS 11. However, even though BAR 2 maybe within uncertainty of MIS 11 in some instances of the age-depth modeling exercise presented here, there is little age control around this time and no direct support for this scenario at present.

\subsection{Stacking Expedition 354 Records to Establish a Regional Signal}

As each Expedition 354 site has imperfect recovery, an incomplete record of fan deposition, and significant uncertainty in its age-depth model, we explore the regional signal spanning the $320 \mathrm{~km}$ of the transect at $8^{\circ} \mathrm{N}$. To do so, we build two data stacks, one for sediment accumulation rates and one for MS, using the age models presented here. These stacks are meant to simulate an integrated signal across $8^{\circ} \mathrm{N}$ from the most recently active channel to the west flank of the Ninetyeast Ridge. This signal would not include sediments deposited further to the west, which has been the main depocenter of the Bengal Fan since the establishment of the most recent subfan in the late Pleistocene (Bergmann et al., 2020; Curray et al., 2003; Schwenk \& Spiess, 2009) and potentially a depocenter while the middle Pleistocene hemipelagic unit was deposited along our transect (Bergmann et al., 2020). While the Nicobar Fan may have been an important depocenter for parts of the Neogene, a prominent reflector that marks the end of high accumulation rates on the Nicobar Fan was dated to the early Pleistocene (McNeill et al., 2017), meaning the Nicobar Fan was likely not a 
significant sink for sediments during the time period discussed here. The location of the depocenter for turbiditic sediments during the $300 \mathrm{kyr}$ middle Pleistocene interval when no turbidites were recovered along this transect ( 1.25-0.94 Ma; Weber \& Reilly, 2018) is still unknown.

Our sediment accumulation rate stack median and $1 \sigma$ intervals are plotted in Figure 10. While median values give a sense for the transect-wide changes in sediment accumulation, the variance could illustrate greater uncertainty in our age models or increased variability between sites. Successions of active channel-levee systems with limited chronostratigraphic constraints would contribute to each of these interpretations. Our MS stack shows similar changes, reflecting low values in the low accumulation hemipelagic deposits and higher values as lithogenic contribution increases and particle sizes become coarser. Similar to the accumulation rate stacks, increased variance can reflect increased chronologic uncertainty or increased variability between sites (Figure 10).

We find that following the transect-wide middle Pleistocene hemipelagic layer, where no turbidites were recovered between MIS 37 and MIS 25 (1.25-0.94 Ma), sediment accumulation rate variance increased through about MIS 17 (0.68 Ma) reflecting the onset of turbidite deposition at some sites along the transect. Accumulation rate median and variance begin to increase significantly following MIS 17, reaching peak levels between 0.3 and 0.5 Ma before movement of the depocenter west of the $85^{\circ}$ East Basement Ridge between 0.2 and $0.3 \mathrm{Ma}$.

\subsection{Insights to the Middle to Late Pleistocene Evolution of the Bengal Fan}

We compare our $8^{\circ} \mathrm{N}$ stacked records with what has been argued, but not demonstrated, to be a regionally integrated record of sediment input to the Bay of Bengal and Bengal Fan (Klootwijk et al., 1992; Prell \& Kutzbach, 1997; Zhisheng et al., 2001; Figure 10). We use the ODP Site 758 (5.38 ${ }^{\circ}$ ) MS record after removing MS highs associated with Tephra Layers A through I (Dehn et al., 1991; Farrell \& Janecek, 1991) with chronology assigned using the benthic $\delta^{18} \mathrm{O}$ record of Chen et al. (1995) aligned by Lisiecki and Raymo (2005). The MS is smoothed using a 40 kyr FWHM Gaussian filter and resampled every 1 kyr to highlight the lower frequency signal. We find broad similarity with our reconstruction, including low MS values coeval with the middle Pleistocene hemipelagic layer observed along the IODP Expedition 354 transect, an increase in MS coeval with a general trend of increased variance and median accumulation rates across the Expedition 354 transect, and a decrease in MS coeval with movement of the Bengal Fan depocenter to the west and more distal to the Ninetyeast Ridge. While it is difficult to make direct comparisons to the ODP Leg 116 Distal Bengal Fan drill sites, we note that increases in Pleistocene sediment accumulation rates at distal Bengal Fan Sites 717 and $719\left(\sim 1^{\circ} \mathrm{S}\right)$ must have occurred during the development of the middle to upper Pleistocene channel-levee systems along our transect and/or subsequent shift of the depocenter to the more western fan at $8^{\circ} \mathrm{N}$.

Our observations suggest a major change in sediment routing on the fan during the middle to late Pleistocene that could be interpreted as the development of a more extensive channel-levee system after about $0.94 \mathrm{Ma}$. This is supported by multiple lines of evidence documenting regional changes following deposition of the regionally extensive middle Pleistocene hemipelagic unit at $8^{\circ} \mathrm{N}$ and subsequent increases in MS and accumulation rates. First, based on seismic observations of the BAR horizons along $8^{\circ} \mathrm{N}$ and relative changes in the thickness of each unit, turbiditic sediments were delivered as a series of progressively larger pulses. While there are still uncertainties in the timing of these pulses, seismic unit thickness illustrates each fan building episode was larger than the last, suggesting closer proximity to the center of the active depocenter, a higher rate of sediment delivery, or a longer duration of channel-levee activity. Second, sites from the very distal fan see an increase in accumulation during the time in which progressive episodes of fan building at $8^{\circ} \mathrm{N}$ become larger. And finally, the long-term pattern of sediment accumulation on the eastern lower fan at $8^{\circ} \mathrm{N}$ is remarkably similar to the long-term pattern in lithogenic concentration at the closest pelagic reference site, ODP Site 758, supporting earlier claims that this signal reflects an integrated record of sedimentation and sediment routing on the Bengal Fan and, likely, for this timeframe is influenced by processes occurring on the eastern lower Bengal Fan.

It is important to note that these observations on their own do not necessarily make the late Pleistocene unique, as channel levee systems were present at $8^{\circ} \mathrm{N}$ during times since the late Miocene (France-Lanord et al., 2016; Schwenk \& Spiess, 2009) and higher accumulation rates are observed at 


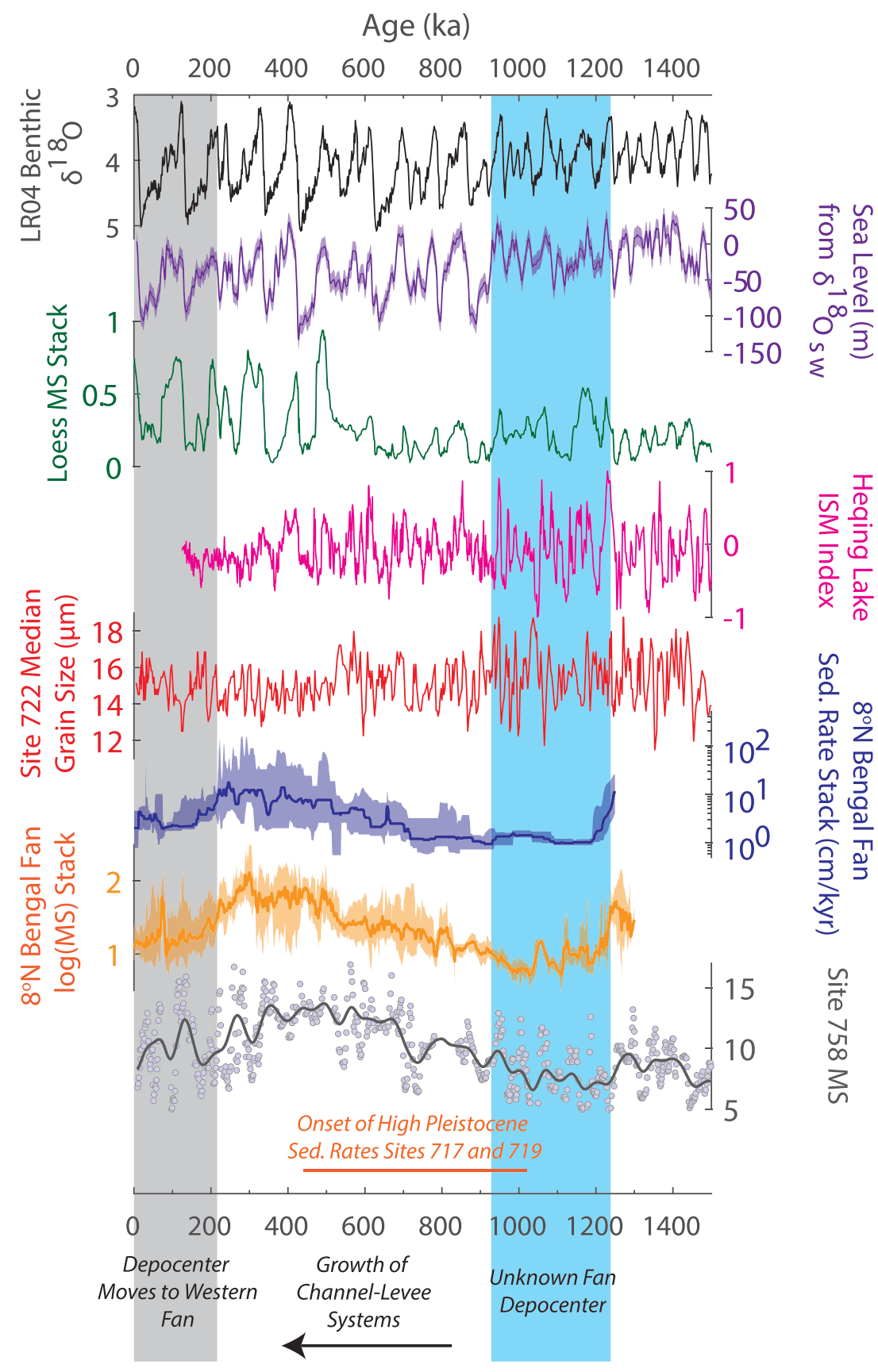

Figure 10. Stacked Bengal Fan sediment accumulation rates and magnetic susceptibility (MS) at $8^{\circ} \mathrm{N}$ in the context of regional and global records. (from top to bottom) The LR04 benthic $\delta^{18} \mathrm{O}$ stack which is a signal of deep sea temperature and global ice volume (Lisiecki \& Raymo, 2005); global sea level estimates from temperature-corrected benthic $\delta^{18} \mathrm{O}$ (Elderfield et al., 2012; Rohling et al., 2014); MS from the Chinese Loess Plateau which is a signal of East Asian summer monsoon intensity (Sun et al., 2006); Heqing Lake Indian summer monsoon (ISM) index which used a stack of proxies sensitive to temperature, precipitation, and weathering in the lake's watershed (Zhisheng et al., 2011); ODP Site 722 median grain size which tracks wind strength of the Indian summer monsoon in the Arabian Sea (Clemens, 1998; Clemens et al., 1996) sedimentation rate stack in $\mathrm{cm} / \mathrm{kyr}$ median (line) and $1 \sigma$ interval (purple shading) of the seven Expedition 354 sites at $8^{\circ} \mathrm{N}$ on the Bengal Fan; $\log \left(\mathrm{MS}\right.$ ) stack mean (line) and $1 \sigma$ interval (orange shading) of the seven Expedition 354 sites at $8^{\circ} \mathrm{N}$ on the Bengal Fan; ODP Site 758 MS (Farrell \& Janecek, 1991) which has been interpreted as an integrated signal of sediment flux to the Bay of Bengal and/or Bengal Fan, with tephra layers removed and smoothed using a $40 \mathrm{kyr}$ FWHM Gaussian filter; and range for the possible age of Pleistocene sedimentation rate increases at Sites 717/719 to the southwest of the Expedition 354 transect (Gartner, 1990). The blue highlighted box indicates the time interval where no turbidites were recovered along the Expedition 354 transect and middle Pleistocene chronology is best resolved (Unit 2a in Weber \& Reilly, 2018). Gray shading indicates when the depocenter was focused on the more western fan, as recognized in seismic data (Bergmann et al., 2020; Schwenk \& Spiess, 2009). 
distal fan sites during Miocene and Pliocene times (Gartner, 1990). However, the middle to late Pleistocene is unique in that we have better age control and can discuss this specific change within the context of regional and global records.

In general, long-term accumulation rates are controlled by changes in sediment supply, sediment transport, and accommodation space. We cannot rule out that the changes we observe at $8^{\circ} \mathrm{N}$ are controlled by stochastic fan sediment transport processes. However, long-term changes in sediment supply to the Bay of Bengal is likely influenced by long-term trends in climatically or tectonically driven erosion and sea level variations influence on continental shelf accommodation space and the connection between the major Himalayan river systems and the deep ocean.

We do not have a complete understanding of how sedimentary proxy records, such as sedimentological, magnetic, or geochemical parameters, reflect the long-term Pleistocene evolution of Asian monsoonal systems and which proxies reflect regional versus local signals. While evidence from the Chinese Loess Plateau indicate strengthening of interglacial summer monsoons and associated precipitation from the middle to late Pleistocene (Sun et al., 2006), this change is likely not representative of the Indian summer monsoon and not in sync with where we observe our initial increases in accumulation rate, with the largest intensifications of the East Asian summer monsoon around 1.25 and 0.6 Ma (Figure 10). Grain size changes in the Arabian Sea that reflect the Indian summer monsoon wind strength (Clemens et al., 1996; Clemens, 1998) and precipitation and weathering proxies from Heqing Lake in Southern China (Zhisheng et al., 2011) suggest that Indian summer monsoon may have weakened during the late Pleistocene as Northern Hemisphere glaciation intensified.

We do observe, however, that the onset of the middle to late Pleistocene growth of the Bengal Fan channel-levee system, as detected at $8^{\circ} \mathrm{N}$ following $0.94 \mathrm{Ma}$, occurs during the first very low sea level stand of the middle to late Pleistocene, as recognized in the ice volume signal of temperature-corrected benthic foraminifera $\delta^{18} \mathrm{O}$ (Elderfield et al., 2012; Figure 10) and sea level-controlled hydrologic cycle signals in Mediterranean Sea planktonic foraminifera $\delta^{18}$ O (Rohling et al., 2014). Based on this observation, we hypothesize that the evolution of the middle to late Pleistocene Bengal Fan was driven by the increase in glacial-interglaciation sea level amplitude, which strengthened the connection between Himalayan Rivers and the Bengal Fan and potentially the erosion of sediment on the shelf and flood plain. However, changes in Pleistocene climate around the same time, in either glacial or interglacial times, could have also strengthened the erosional regime in the Himalaya Mountains and increased sediment flux to the Bay of Bengal. Further work is required to investigate these hypotheses.

\section{Conclusion}

We investigate the evolution of the middle to upper Pleistocene Bengal Fan at seven sites along the IODP Expedition $3548^{\circ} \mathrm{N}$ transect using a system-specific age modeling approach that assesses uncertainty and incorporates expert knowledge of the fan. Sediment accumulation rates are low during a $300 \mathrm{kyr}$ interval ( 1.25-0.94 Ma) where no turbidites are observed across the $320 \mathrm{~km}$ transect both to the west (IODP Site U1454) and east (IODP Sites U1449 to U1453 and U1455) of the $85^{\circ}$ east basement ridge. During this time, the depocenter must have been elsewhere on the fan, with thick fan deposits possibly spatially restricted further to the north and/or further to the west (Subfan B of Bergmann et al., 2020); however, the specific extent and nature of the $1.25-0.94$ Ma depocenter is still unknown. Following $0.94 \mathrm{Ma}$, sediment accumulation rates gradually increased. This observation, along with seismic observations, accumulation rates on the distal fan, and lithogenic sediment concentrations at a pelagic reference site, indicate development of the Bengal Fan channel-levee system during this time to a distribution network that covers a greater extent of the fan, primarily east of the $85^{\circ}$ east basement ridge (Subfan $\mathrm{C}$ of Bergmann et al., 2020). By $\sim 0.2 \mathrm{Ma}$, the depocenter shifts to east of the $85^{\circ}$ east basement ridge at $8^{\circ} \mathrm{N}$ but also appears to have a large spatial extent in seismic imaging (Subfan D of Bergmann et al., 2020). The onset of the initial growth to a more extensive fan after $0.94 \mathrm{Ma}$ is coincident with the first major sea level low of the middle to late Pleistocene, leading us to hypothesize that increased sea level amplitude changes associated with amplification of polar glaciation was a major driver of Pleistocene Bengal Fan changes. 


\section{Acknowledgments}

We are grateful to the captain, crew, IODP staff, and shipboard scientists on the JOIDES Resolution that made IODP Expedition 354 and subsequent research successful. All samples and core data were provided by IODP. This work was made possible by support from a U.S. Science Support Program post expedition award to B. T. R. We thank Leslie and Mark Workman and the Oregon ARCS Foundation for additional support to B. T. R. The collaboration that resulted in this paper was strengthened by a travel grant from the Bremen International Graduate School for Marine Science (GLOMAR) which supported F. B.'s visit to Oregon State University. Collection of seismic data was funded by BMFT Project 03 G 0093 A (SO93), BMBF Grant 03 G 0125A (SO125), and BMBF Grant 03 G 0188A (SO188). F. B. and M. E. W were supported by funding from the German Research Foundation (DFG) within the IODP Priority program (SCHW1551/7-1/2 and We2039/14-1). This study benefited greatly from a discussion with Andreas Nilsson, who recommended the use of the T-walk algorithm. Data are archived in the IODP Community at Zenodo.org along with the shipboard expedition data (http://doi.org/10.5281/ zenodo.3676057). We thank Claudio Faccenna (Editor), Stephen Phillips (reviewer), and two anonymous reviewers for helpful and constructive comments that improved this manuscript.

\section{References}

Ahmad, S. M., Anil, B. G., Padmakumari, V. M., Dayal, A. M., Sukhija, B. S., \& Nagabhushanam, P. (2005). Sr, Nd isotopic evidence of terrigenous flux variations in the Bay of Bengal: Implications of monsoons during the last $\sim 34,000$ years. Geophysical Research Letters, 32, L2271. https://doi.org/10.1029/2005GL024519

Bahk, J.-J., Um, I.-K., \& Shin, K.-H. (2019). Contrasting developments of Pleistocene calcareous clay units in the middle Bengal Fan and their implications for paleoenvironmental changes. Geosciences Journal, 23(6), 867-879. https://doi.org/10.1007/s12303-019-0012-0

Bergmann, F. (2018). The Bengal Fan on different temporal and spatial scales: Integrating seismoacoustic and IODP Expedition 354 data to examine internal and external controls on depositional processes (dissertation). Universität Bremen: Geowissenschaften, Bremen, Germany. Retrieved from https://elib.suub.uni-bremen.de/edocs/00106937-1.pdf

Bergmann, F., Schwenk, T., Spiess, V., \& France-Lanord, C. (2020). Middle to Late Pleistocene architecture and stratigraphy of the lower Bengal Fan-Integrating multichannel seismic data and IODP Expedition 354 result. Geochemistry, Geophysics, Geosystems, 21, e2019GC008702. https://doi.org/10.1029/2019GC008702

Blaauw, M., \& Christen, J. A. (2011). Flexible paleoclimate age-depth models using an autoregressive gamma process. Bayesian Analysis, 6(3), 457-474. https://doi.org/10.1214/ba/1339616472

Blum, M., Rogers, K., Gleason, J., Najman, Y., Cruz, J., \& Fox, L. (2018). Allogenic and autogenic signals in the stratigraphic record of the Deep-Sea Bengal Fan. Scientific Reports, 8(1), 7973. https://doi.org/10.1038/s41598-018-25819-5

Channell, J. E. T., Hodell, D. A., \& Curtis, J. H. (2016). Relative paleointensity (RPI) and oxygen isotope stratigraphy at IODP Site U1308: North Atlantic RPI stack for 1.2-2.2 Ma (NARPI-2200) and age of the Olduvai Subchron. Quaternary Science Reviews, 131, 1-19. https://doi.org/10.1016/j.quascirev.2015.10.011

Chen, J., Farrell, J., Murray, D., \& Prell, W. (1995). Timescale and paleoceanographic implications of a 3.6 m.y. oxygen isotope record from the northeast Indian Ocean (Ocean Drilling Program Site 758). Paleoceanography, 10(1), 21-47. https://doi.org/10.1029/94PA02290

Chesner, C. A. (2012). The Toba Caldera complex. Quaternary International, 258, 5-18. https://doi.org/10.1016/j.quaint.2011.09.025

Christen, J. A., \& Fox, C. (2010). A general purpose sampling algorithm for continuous distributions (the t-walk). Bayesian Analysis, 5(2), 263-281. https://doi.org/10.1214/10-BA60

Clark, P. U., Archer, D., Pollard, D., Blum, J. D., Rial, J. A., Brovkin, V., et al. (2006). The middle Pleistocene transition: Characteristics, mechanisms, and implications for long-term changes in atmospheric pCO2. Quaternary Science Reviews, 25(23-24), 3150-3184. https://doi.org/10.1016/j.quascirev.2006.07.008

Clemens, S. C., Kuhnt, W., LeVay, L. J., Anand, P., Ando, T., Bartol, M., et al. (2016). Site U1443. In S. C. Clemens, W. Kuhnt, \& L. J. LeVay (Eds.). and the Expedition 353 Scientists, Indian Monsoon Rainfall. Proceedings of the International Ocean Discovery Program (Vol. 353). College Station, TX: International Ocean Discovery Program. https://doi.org/10.14379/iodp.proc.353.103.2016

Clemens, S. C. (1998). Dust response to seasonal atmospheric forcing: Proxy evaluation and calibration. Paleoceanography, 13(5), 471-490. https://doi.org/10.1029/98PA02131

Clemens, S. C., Murray, D. W., \& Prell, W. L. (1996). Nonstationary phase of the Plio-Pleistocene Asian monsoon. Science, 274(5289), 943-948. https://doi.org/10.1126/science.274.5289.943

Curray, J. R. (1994). Sediment volume and mass beneath the Bay of Bengal. Earth and Planetary Science Letters, 125(1-4), 371-383. https://doi.org/10.1016/0012-821X(94)90227-5

Curray, J. R., Emmel, F. J., \& Moore, D. G. (2003). The Bengal Fan: Morphology, geometry, stratigraphy, history and processes. Marine and Petroleum Geology, 19(10), 1191-1223. https://doi.org/10.1016/S0264-8172(03)00035-7

Curray, J. R., \& Moore, D. G. (1974). Sedimentary and tectonic processes in the Bengal Deep-Sea fan and geosyncline. In C. A. Burk, \& C. L. Drake (Eds.), The geology of continental margins, (pp. 617-627). Berlin Heidelberg: Springer. https://doi.org/10.1007/ 978-3-662-01141-6_45

Dehn, J., Farrell, J. W., \& Schmincke, H. U. (1991). Neogene tephrochronology from Site 758 on northern Ninetyeast Ridge: Indonesian arc volcanism of the past 5 Ma. In Proceedings of the Ocean Drilling Program, Scientific Results (Vol. 121, pp. 273-295). College Station, TX: Ocean Drilling Program. https://doi.org/10.2973/odp.proc.sr.121.123.1991

Elderfield, H., Ferretti, P., Greaves, M., Crowhurst, S., McCave, I. N., Hodell, D., \& Piotrowski, A. M. (2012). Evolution of ocean temperature and ice volume through the mid-Pleistocene climate transition. Science, 337(6095), 704-709. https://doi.org/10.1126/ science.1221294

Farrell, J. W., \& Janecek, T. R. (1991). 15. Late Neogene paleoceanography and paleoclimatology of the northeast Indian Ocean (Site 758). In Proceedings of the Ocean Drilling Program, Scientific Results (Vol. 121, pp. 297-355). College Station, TX: Ocean Drilling Program.

France-Lanord, C., Spiess, V., Klaus, A., Schwenk, T., \& the Expedition 354 scientists (2016). Bengal Fan. In Proceedings of the International Ocean Discovery Program (Vol. 354). College Station, TX: International Ocean Discovery Program. Retrieved from https://doi.org/ 10.14379/iodp.proc.354.2016

France-Lanord, C., \& Derry, L. A. (1997). Organic carbon burial forcing of the carbon cycle from Himalayan erosion. Nature, 390(6655), 65-67. https://doi.org/10.1038/36324

France-Lanord, C., Derry, L. A., \& Michard, A. (1993). Evolution of the Himalaya since Miocene time: Isotopic and sedimentological evidence from the Bengal Fan. In P. J. Treloar \& M. P. Searle (Eds.), Himalayan tectonics (pp. 603-621). London: Geological Society

Galy, V., France-Lanord, C., Beyssac, O., Faure, P., Kudrass, H., \& Palhol, F. (2007). Efficient organic carbon burial in the Bengal Fan sustained by the Himalayan erosional system. Nature, 450(7168), 407-410. https://doi.org/10.1038/nature06273

Gartner, S. (1990). Neogene calcareous nannofossil biostratigraphy, Leg 116 (central Indian Ocean). In J. R. Cochran, D. A. V. Stow, et al. (Eds.), Proceeding Ocean Drilling Program, Scientific Results (Vol. 116, pp. 165-187). College, Station, TX: Ocean Drilling Program.

Gradstein, F. M., Ogg, J., Schmitz, M., \& Ogg, G. (Eds.). (2012). The geologic time scale 2012 (1st edn.). Amsterdam: Elsevier.

Haslett, J., \& Parnell, A. (2008). A simple monotone process with application to radiocarbon-dated depth chronologies. Journal of the Royal Statistical Society: Series C: Applied Statistics, 57(4), 399-418. https://doi.org/10.1111/j.1467-9876.2008.00623.x

Hein, C. J., Galy, V., Galy, A., France-Lanord, C., Kudrass, H., \& Schwenk, T. (2017). Post-glacial climate forcing of surface processes in the Ganges-Brahmaputra river basin and implications for carbon sequestration. Earth and Planetary Science Letters, 478, 89-101. https://doi.org/10.1016/j.epsl.2017.08.013

Klootwijk, C. T., Gee, J. S., Peirce, J. W., \& Smith, G. M. (1992). Neogene evolution of the Himalayan-Tibetan region: Constraints from ODP Site 758, northern Ninetyeast ridge; bearing on climatic change. Palaeogeography, Palaeoclimatology, Palaeoecology, 95(1), 95-110. https://doi.org/10.1016/0031-0182(92)90167-4

Lee, M.-Y., Chen, C.-H., Wei, K.-Y., Iizuka, Y., \& Carey, S. (2004). First Toba supereruption revival. Geology, 32(1), 61-64. https://doi.org/ 10.1130/G19903.1 
Lisiecki, L. E., \& Raymo, M. E. (2005). A Pliocene-Pleistocene stack of 57 globally distributed benthic $\delta^{18}$ O records. Paleoceanography, 20, PA1003. https://doi.org/10.1029/2004PA001071

Lupker, M., France-Lanord, C., Galy, V., Lavé, J., \& Kudrass, H. (2013). Increasing chemical weathering in the Himalayan system since the Last Glacial Maximum. Earth and Planetary Science Letters, 365, 243-252. https://doi.org/10.1016/j.epsl.2013.01.038

Mark, D. F., Renne, P. R., Dymock, R., Smith, V. C., Simon, J. I., Morgan, L. E., Richard A. Staff, et al. (2017). High-precision ${ }^{40} \mathrm{Ar} /{ }^{39} \mathrm{Ar}$ dating of Pleistocene tuffs and temporal anchoring of the Matuyama-Brunhes boundary. Quaternary Geochronology, 39, 1-23. https://doi.org/10.1016/j.quageo.2017.01.002

McNeill, L. C., Dugan, B., Backman, J., Pickering, K. T., Pouderoux, H. F. A., Henstock, T. J., et al. (2017). Understanding Himalayan erosion and the significance of the Nicobar Fan. Earth and Planetary Science Letters, 475, 134-142. https://doi.org/10.1016/j. epsl.2017.07.019

Nilsson, A., Suttie, N., \& Hill, M. J. (2018). Short-term magnetic field variations from the post-depositional remanence of lake sediments. Frontiers in Earth Science, 6, 39. https://doi.org/10.3389/feart.2018.00039

Phillips, S. C., Johnson, J. E., Giosan, L., \& Rose, K. (2014). Monsoon-influenced variation in productivity and lithogenic sediment flux since $110 \mathrm{ka}$ in the offshore Mahanadi Basin, northern Bay of Bengal. Marine and Petroleum Geology, 58, 502-525. https://doi.org/ 10.1016/j.marpetgeo.2014.05.007

Piper, D. J. W., \& Normark, W. R. (1983). Turbidite depositional patterns and flow characteristics, Navy Submarine Fan, California borderland. Sedimentology, 30(5), 681-694. https://doi.org/10.1111/j.1365-3091.1983.tb00702.x

Prell, W. L., \& Kutzbach, J. E. (1997). The impact of Tibet-Himalayan elevation on the sensitivity of the monsoon climate system to changes in solar radiation. In Tectonic uplift and climate change (pp. 171-201). New York: Springer.

Raymo, M. E., \& Ruddiman, W. F. (1992). Tectonic forcing of late Cenozoic climate. Nature, 359(6391), 117-122. https://doi.org/10.1038/ $359117 \mathrm{a} 0$

Reilly, B. T., Stoner, J. S., Selkin, P. A., Savian, J., \& Meynadier, L. (2018). Data report: Paleomagnetic directions from IODP Expedition 354, Hole U1451A, Cores 23H and 24H. In C. France-Lanord, V. Spiess, A. Klaus, T. Schwenk, \& the Expedition 354 scientists (Eds.), Bengal Fan (Vol. 354, pp. 1-7). College Station, TX: International Ocean discovery program. https://doi.org/10.14379/iodp.proc.354.201.2018

Rohling, E. J., Foster, G. L., Grant, K. M., Marino, G., Roberts, A. P., Tamisiea, M. E., \& Williams, F. (2014). Sea-level and deep-sea-temperature variability over the past 5.3 million years. Nature, 508(7497), 477-482. https://doi.org/10.1038/nature13230

Sager, W. W., \& Hall, S. (1990). 26. Magnetic properties of black mud turbidites from ODP Leg 116, distal Bengal Fan, Indian Ocean. In Proceedings of the Ocean Drilling Program, Scientific Results (Chap. 26, Vol. 116, pages 317-336). College Station, TX: Ocean Drilling Program.

Schwenk, T., \& Spiess, V. (2009). Architecture and stratigraphy of the Bengal Fan as response to tectonic and climate revealed from high-resolution seismic data. In B. C. Kneller, O. J. Martinsen, \& B. McCaffrey (Eds.), External controls on deep-water depositional systems (pp. 107-131). Tulsa, Okla: SEPM (Society for Sedimentary Geology).

Schwenk, T., Spiess, V., Breitzke, M., \& Hübscher, C. (2005). The architecture and evolution of the middle Bengal Fan in vicinity of the active channel-levee system imaged by high-resolution seismic data. Marine and Petroleum Geology, 22(5), 637-656. https://doi.org/ 10.1016/j.marpetgeo.2005.01.007

Schwenk, T., Spiess, V., Hübscher, C., \& Breitzke, M. (2003). Frequent channel avulsions within the active channel-levee system of the middle Bengal Fan - An exceptional channel-levee development derived from Parasound and Hydrosweep data. Deep Sea Research Part II: Topical Studies in Oceanography, 50(5), 1023-1045. https://doi.org/10.1016/S0967-0645(02)00618-5

Smit, J., van Eijden, A. J. M., \& Troelstra, S. R. (1991). Analysis of the Australasian microtektite event, the Toba Lake event, and the Cretaceous/Paleogene boundary, eastern Indian Ocean. In Proceedings of the Ocean Drilling Program, Scientific Results (Vol. 121, pp. 489-503). College Station, TX: Ocean Drilling Program.

Sun, Y., Clemens, S. C., An, Z., \& Yu, Z. (2006). Astronomical timescale and palaeoclimatic implication of stacked 3.6-Myr monsoon records from the Chinese Loess Plateau. Quaternary Science Reviews, 25(1), 33-48. https://doi.org/10.1016/j.quascirev.2005.07.005

Sun, Y., Yin, Q., Crucifix, M., Clemens, S. C., Araya-Melo, P., Liu, W., et al. (2019). Diverse manifestations of the mid-Pleistocene climate transition. Nature Communications, 10(1), 1, 352-11. https://doi.org/10.1038/s41467-018-08257-9

Von der Borch, C. C., Sclater, J. G., Gartner, S. Jr., Hekinian, R., Johnson, D. A., McGowran, B., et al. (1974). Initial reports of the Deep Sea Drilling Project (Vol. 22). Washington, DC: U.S. Government Printing Office.

Walczak, M. H., Mix, A. C., Willse, T., Slagle, A., Stoner, J. S., Jaeger, J., et al., \& the IODP Expedition 341 Scientific Party (2015). Correction of non-intrusive drill core physical properties data for variability in recovered sediment volume. Geophysical Journal International, 202 (2), 1317-1323. https://doi.org/10.1093/gji/ggv204

Weber, M. E., Lantzsch, H., Dekens, P., Das, S. K., Reilly, B. T., Martos, Y. M., et al. (2018). 200,000 years of monsoonal history recorded on the lower Bengal Fan-Strong response to insolation forcing. Global and Planetary Change, 166, 107-119. https://doi.org/10.1016/j. gloplacha.2018.04.003

Weber, M. E., \& Reilly, B. T. (2018). Hemipelagic and turbiditic deposits constrain lower Bengal Fan depositional history through Pleistocene climate, monsoon, and sea level transitions. Quaternary Science Reviews, 199, 159-173. https://doi.org/10.1016/j. quascirev.2018.09.027

Weber, M. E., Wiedicke, M., Kudrass, H., Hübscher, C., \& Erlenkeuser, H. (1997). Active growth of the Bengal Fan during sea-level rise and highstand. Geology, 25(4), 315-318. https://doi.org/10.1130/0091-7613(1997)025<0315:AGOTBF>2.3.CO;2

Weber, M. E., Wiedicke-Hombach, M., Kudrass, H. R., \& Erlenkeuser, H. (2003). Bengal Fan sediment transport activity and response to climate forcing inferred from sediment physical properties. Sedimentary Geology, 155(3-4), 361-381. https://doi.org/10.1016/S0037-0738 (02)00187-2

Zhisheng, A., Clemens, S. C., Shen, J., Qiang, X., Jin, Z., Sun, Y., et al. (2011). Glacial-interglacial Indian summer monsoon dynamics. Science, 333(6043), 719-723. https://doi.org/10.1126/science.1203752

Zhisheng, A., Kutzbach, J. E., Prell, W. L., \& Porter, S. C. (2001). Evolution of the Asian monsoons and phased uplift of the Himalaya-Tibetan plateau since Late Miocene times. Nature, 411(6833), 62-66. https://doi.org/10.1038/35075035 